\title{
Migration and geopolitical preferences
}

\begin{abstract}
This paper investigates the impact of work experience abroad on migrants' geopolitical preferences. For this purpose we analyse representative survey data from Moldova, a country caught in an ideological battle between Russia and the West, with high emigration rates to both destinations. In a first step, we show that return migrants from the West are significantly more likely to support EU accession than non-migrants, while return migrants from the East are more likely to support closer ties with Russia, controlling for economic, demographic and ethnic confounding factors. In a second step, we use district-level variation in migrant networks as an instrument for individual migration. Second stage regressions show that work experience in the West increases support for EU accession, while no evidence of causal effects is found for work experience in the East. Differences in information exposure and migration policies between the EU and Russia may explain this asymmetry.
\end{abstract}

JEL Classification:P3, J61, D83.

Key words: return migration, political preferences, Moldova, survey data. 


\section{Introduction}

Large scale migration can shape economic and institutional development in origin countries through various mechanisms. Some of these are well known: shifts in the supply of labour and skills change aggregate resource endowments, which may affect production, trade and income distribution; remittances increase consumption and investment; cross-border networks foster trade and foreign direct investment; migrant self-selection among the younger and less risk averse population may increase the dependency ratio and reduce entrepreneurship; the return of migrants with new ideas and capital may stimulate investment and innovation. A less well known dimension of the relationship between migration and development is the impact of living abroad on migrants' political preferences. This paper sheds light on this dimension in the case of temporary labour migration from Moldova.

Living abroad can change an individual's political preferences for two main reasons. First, it implies exposure to new information. Migrants have access to other media channels, they observe different policies and institutions, and their social networks expand. This new information may change migrants' opinions on the desirability of certain policy regimes. Second, it allows migrants to accumulate financial, human and social capital. These socioeconomic changes may alter migrants' benefit from certain policies. As a result, particularly when emigration is non negligible, electoral outcomes in origin countries may be affected through return migration, votes at Embassies in foreign countries and exchanges of ideas between migrants and their social networks at home.

The existence of political spill-over effects of migration has been documented in a small but growing body of empirical research. Using country-level data, several papers have shown that migration improves political institutions in source countries ( $\mathrm{Li}$ and McHale, 2006; 
Spilimbergo, 2009; Beine and Sekkat, 2013; Mercier, 2016; Docquier et al. 2016). Other studies have used locality-level data to show that migration increases voter turnout (Chauvet and Mercier, 2014) and affects electoral results (Pfutze, 2012; Barsbai et al., 2017). Finally, some papers used individual-level data to show that migration experience (or close contacts with migrants) is significantly associated with critical assessment of governance and civic activism (Perez-Armendariz and Crow, 2010; Batista and Vicente, 2011; Nikolova et al., 2017), and with electoral preferences (Fidrmuc and Doyle, 2006). Some of the studies in this literature found that the political spill-over effects of migration are contingent upon the characteristics of destination countries (Fidrmuc and Doyle, 2006; Spilimbergo, 2009; Batista and Vicente, 2011; Chauvet and Mercier, 2014; Barsbai, 2017, Nikolova et al., 2017), of origin countries (Mercier, 2016), and of the migrants (Beine and Sekkat, 2013).

We contribute to this literature by analysing geopolitical preferences in relation with work experience abroad, which, to the best of our knowledge, has not been done before. ${ }^{1}$ In many countries, public opinion on geopolitics is only of secondary importance in political debates, which may explain why the issue has been neglected by the literature so far. In Moldova and some other former communist countries however, the issue is of primary importance. These countries face a choice between closer economic and political ties with Russia and closer ties with the European Union (EU). This choice will have consequences on trade, migration and investment patterns, and is also likely to affect the evolution of regulations,

\footnotetext{
${ }^{1}$ The share of votes for the Communist party in Moldova, analyzed in Barsbai et al (2017) in relation with localitylevel emigration could be viewed as a proxy for geopolitical preferences, since the Communist party has traditionally been in favor of closer relationships with Russia. This is however a noisy indicator of geopolitical preferences, for two reasons. First, the decision to vote for the communist party is based on a vector of expected policies and electoral promises, out of which the geopolitical orientation is only one element. Second, the geopolitical strategy of the Communist Party has not always been consistent. For instance, the leader of the Communist Party and head of state between 2001 and 2009, has made a number of declarations mentioning Moldova's EU aspirations and commitment to European values and principles, and approved the implementation of the EU-Moldova action plan in 2005 (Korosteleva, 2010).
} 
policies and institutions. We want to investigate whether and how migration shapes this important collective decision.

The data used in this paper is similar to Perez-Armendariz and Crow (2010), i.e. individual-level survey data on political opinions and migration experience. The identification strategy is similar to Batista and Vicente (2011), who also use lagged local-level migrant networks as an instrument for individual migration. ${ }^{2}$ The geographic focus is closest to Barsbai et al. (2017), who also use data from Moldova and differentiate between Eastern and Western destinations. $^{3}$

Our analyses consistently show that work experience in Western countries increases support for EU accession and decreases support for closer ties with Russia. On the other hand, we do not find evidence of a causal impact on geopolitical preferences for work experience in Eastern countries.

The remainder of the paper is organized as follows. Section 2 provides a brief overview of politics and emigration patterns in Moldova. Theoretical considerations are discussed in Section 3. Data and the empirical strategy are presented in Section 4. Regression results are discussed in Section 5. Section 6 concludes.

\footnotetext{
${ }^{2}$ Two differences in the construction of instruments may be worth mentioning. First, the data we use for constructing the lagged local-level migrant stocks come from a population census conducted eight years before the survey, while Batista and Vicente (2011) construct five-year lagged local migrant stocks based on survey questions on households' migration history. Second, Batista and Vicente (2011) use economic indicators for Portugal and the United States, the main destination countries for Cape-Verdean migrants, as additional instruments for migration. Constructing similar additional instruments would be less straightforward in the case of Moldova, due to the multiplicity of destination countries.

${ }^{3}$ The classification of destination countries into East and West is based on the quality of institutions in Barsbai et al. (2017), while in this paper it is based solely on geography.
} 


\section{Geopolitics and migration patterns in Moldova}

Moldova is a South Eastern European country of 3.5 million inhabitants, landlocked between Romania, an EU member state, and Ukraine, a former Soviet republic. The country belonged to Romania in the interwar period and was part of the Soviet Union between the Second World War and 1991, when it became independent. Around 75\% of the population are native Moldovans speaking Romanian at home, and $15 \%$ are native Ukrainians and Russians, speaking Russian at home. The majority of the population has access to media in both languages. Romania and Russia are the country's most important trading partners. Due to its geographic and cultural position, at the border between Eastern and Western civilisations, the country is a strategic battle ground for influence between Russia and the West.

The EU has invested significant resources in the development of political, economic, and security ties with Moldova. The outcomes of these investments include a number of cooperation agreements aimed at aligning legislation, norms and standards to those of the EU in a wide range of domains, from respect for freedom of the media, rights of minorities and transparent elections, to origin of goods, competition and bankruptcy legislation (European Union, 2005). The implementation of reforms has been supported with technical and financial assistance by the EU, Moldova's most important donor. Progress has been monitored by the EU delegation established in Moldova's capital.

The Kremlin has been using a mix of trade and military policies to maintain its economic, political and ideological influence in Moldova. Russia is a major export market for Moldovan agricultural products and its only gas provider. Consequently, the Kremlin's trade policies have a certain leverage on Moldovan policy makers (Korosteleva, 2010). Russian troops and military equipment are stationed in Transnistria, a breakaway territory situated at the 
border with Ukraine, populated by a majority of Russian speakers and receiving important financial support from Russia.

The choice between a European path, leading to closer economic and political ties with the EU and possibly to EU accession in the long run, and a Russian path, leading to Customs Union (CU) accession and possibly to the Eurasian Union in the long run, has been a major policy debate since Moldova's independence from the Soviet Union. The path which the country will take is uncertain at the moment of writing this paper. ${ }^{4}$

The public opinion in Moldova is split into three groups of comparable sizes: those with a strong preference for EU integration, those with a strong preference for closer ties with Russia, and those with no strong preference for either of the two options. To a large extent this division is determined by ethnic and socio-demographic factors. Romanian speakers, younger and more educated Moldovans are generally more in favour of EU integration. Russian speakers and older generations are more likely to support closer ties with Russia. ${ }^{5}$ In addition, public opinions on this question are affected by foreign and domestic events, such as the economic and migrant crises in Europe, terrorist attacks, embargos imposed by Russia, and corruption scandals involving leaders of pro-European or pro-Russia parties. Consequently, the sizes of the three groups varies non negligibly over time. ${ }^{6}$ Another factor which may be influencing the public opinion on this issue is emigration.

\footnotetext{
${ }^{4}$ A pro-European coalition ruled the country between 2009 and 2016 and implemented a number of steps towards closer collaboration with the EU, including the signing in 2014 of a Deep and Comprehensive Association Agreement which liberalized trade and short term mobility with the EU. Since 2016, the country is led by the leader of the pro-Russia Socialist party. Parliamentary elections to be held in February 2019 will determine whether the Socialist party will have the majority necessary for withdrawing from the Association Agreement with the EU. ${ }^{5}$ For example, the 2015 Barometer of Public Opinion report shows these patterns (Institute for Public Policy, 2015) .

${ }^{6}$ Yearly survey data on support for EU integration has been published by the Institute for Public Policy's Barometer of Public Opinion since 2000. According to this data, support for EU integration has fluctuated between $61 \%$ in 2002 and $44 \%$ in 2012, reaching a peak of $76 \%$ in 2007.
} 
Since independence from the Soviet Union in 1991, and particularly after the Russian financial crisis in 1998, Moldova has been experiencing massive waves of emigration. Between a quarter and forty percent of the economically active population is estimated to have had a migration experience (IOM, 2012). The main driving factors are poverty, lack of employment opportunities and low salaries at home (IOM, 2012). Temporary labor migration is the most widespread form of migration. Migrants work in economic sectors where labour force is in demand, which do not necessarily match their pre-migration experience and qualifications. According to a survey conducted in 2007,35 per cent of returning migrants with a university degree worked in construction and 28 per cent worked as domestic workers abroad (IOM, 2012).

Interestingly for the purpose of this study, temporary labor migration has been directed towards both Eastern destinations, predominantly Russia (more than 55\% of Moldovan migrants in 2014) and Western destinations, particularly Italy (more than $15 \%$ of Moldovan migrants in 2014). ${ }^{7}$ Russia is an important destination because no visa is necessary to cross the border, travel by train is relatively inexpensive and the majority of Moldovans have a good knowledge of the Russian language, customs and norms due to the Soviet Union legacy. An important proportion of migrants to Russia are males working in the construction sector (IOM, 2012). Italy is the first destination among Western European countries partly due to the similarity between Romanian and Italian languages and a certain cultural proximity. We will explore this variation in destination countries in order to analyse the impact of work experience abroad on political preferences.

\footnotetext{
7 The International Organization for Migration's Mission to the Republic of Moldova provides a detailed description of migration patterns: http://www.iom.md/migration-profile-republic-moldova.
} 


\section{Theoretical considerations}

Why should work experience in a foreign country have an impact on political preferences? The preferred policy regime of a rational individual is the one which maximises expected utility, given the available information. Life experience abroad can modify an individual's preferred policy regime through two mechanisms: by providing new information about the expected utility in some policy regimes, or by directly changing the expected utility in some policy regimes. These two mechanisms and their testable predictions in the case of Moldovan migration are discussed in the following paragraphs.

A first potential mechanism is new information acquired abroad. In destination countries, migrants have the opportunity to observe the functioning of different institutions and economic systems. They are exposed to alternative ideas, values and world views through social interactions and the media. This new information may change their perceptions of the benefits resulting from some policies or institutions. Such changes are more likely to happen when origin and destination countries differ in terms of institutions, policies or world views, i.e. when the informational shock is sufficiently important. This hypothesis seems to be supported by existent research on the political spill-over effects of migration. ${ }^{8}$ In the case of Moldova, the information hypothesis implies stronger effects for work experience in Western European countries than in former Soviet countries, since the institutions, economic systems and world views present in Moldova are relatively closer to those present in other former Soviet countries. ${ }^{9}$

\footnotetext{
${ }^{8}$ E.g. Chauvet and Mercier (2014) find that the effect of return migration on political participation in Mali is higher for migration to non-African countries; Batista and Vicente (2011) find that the impact of migration on the demand for political accountability in Cape Verde is higher for migration to the US than for migration to Portugal, whereas Cape-Verde is closer to Portugal than to the US in cross-country governance rankings; Nikolova et al. (2017) find that the effect of migration on civic engagement in Romania and Bulgaria is higher for migration to the most civically engaged countries; Mercier (2016) finds that the correlation between political leaders' migration experience and the evolution of democracy during their leadership is higher for migration from developing countries to high income OECD countries.

${ }^{9}$ Institutions and economic systems in former Soviet countries are relatively similar due to the legacy of the Soviet Union. In addition, certain world views persist in former communist countries, as shown by Alesina and FuchsSchundeln (2007).
} 
A second potential mechanism is a migration-induced change in the benefits resulting from some policies or institutions. Such a change may happen for a number of reasons. As migration increases incomes, it may reduce the benefits from social security and redistributive policies for the migrants and their families. Likewise, migrants may accumulate wealth and investment, and consequently have different preferences related to capital taxation and property protection policies. Migrants also acquire information on job prospects and prices in destination countries, as well as social networks and language skills, and may consequently attach a higher value to free mobility to those countries. If the geopolitical choices of origin countries affect mobility constraints, migration may affect geopolitical preferences. At the time of the survey, ${ }^{10}$ a visa was necessary for Moldovan citizens willing to enter EU countries- a constraint which would be removed by EU accession. Work experience in EU countries should therefore increase support for EU accession. At the same time, no visa was necessary for entering Russia- an acquired advantage which would not obviously be improved by closer relationships with Russia. Work experience in Russia is therefore not expected to increase support for closer relations with Russia.

Both theoretical mechanisms described above imply that work experience in Western countries should have a higher causal effect on geopolitical preferences than work experience in former Soviet countries. When using survey data to predict individual geopolitical preferences based on migration experience, the estimated coefficients are likely to capture two effects: the causal impacts of migration and migrant self-selection. If geopolitical preferences before migration are not observed and if individuals with more Western world views are more likely to look for jobs in the West, while pro-Russian individuals are more likely to look for jobs in the East, the coefficients of migration experience will be biased upwards. In addition, if individuals with pro-Western values are less likely to return (and be part of surveys conducted

\footnotetext{
${ }^{10}$ The survey used in this research was conducted in 2012.
} 
in the country of origin), regression coefficients may be biased downwards by self-selection in return decisions. An identification strategy is therefore necessary when testing the theoretical mechanisms described above using cross-section data.

\section{Data and empirical strategy}

We use survey data collected in Moldova in 2012 by the Institute of Public Policy, an independent and non-profit research institute. A representative sample of the adult population was selected through stratified two stage random sampling, with districts and size of localities as stratification criteria. ${ }^{11}$ A total 1237 individuals were surveyed from 88 rural and urban localities, covering all districts and municipalities. Interviews were conducted at respondents' homes. The questionnaire was available in Romanian or Russian and the choice of the language was left to the respondent. The survey included questions on respondent's geopolitical preferences, work experience abroad and socio-demographic characteristics.

We want to investigate whether work experience abroad affects geopolitical preferences. In order to do this, we first regress measures of geopolitical preferences on migration experience, controlling for relevant confounding factors. We then use district-level migrant networks as an instrument for individual migration in order to disentangle the causal effects of work experience abroad from migrant self-selection.

\section{Dependent Variables}

The outcomes of interest are dummy variables EU accession and $C U$ accession, indicating that the respondent would vote in favour of EU and CU accession respectively, if referendums on these questions were organized. As a robustness check, we use a five-point

\footnotetext{
11 Districts are the main administrative units in Moldova. The country is divided into 32 districts, three municipalities including the capital Chisinau, and two autonomous territorial units: Transnistria and Gagauzia. The two autonomous territorial units are not covered by the survey. The stratification sampling method ensures that the selected sample is representative at the district level.
} 
scale measure of geopolitical preferences, EU versus $C U$, indicating how strictly the respondent prefers EU accession to CU accession. Details of how these variables were constructed and descriptive statistics can be found in Table A2.

\section{Explanatory variables of interest}

Our central explanatory variables are dummies representing work experience abroad. Returnee East indicates work experience in an Eastern country, Returnee West indicates work experience in a Western country and Returnee East and West indicates work experience in both Eastern and Western countries. Destinations countries were grouped into East and West based on their geographical position with respect to Moldova. The reference category are respondents who have never worked abroad. Details of how these variables were constructed and descriptive statistics can be found in Table A1.

\section{Control Variables}

Standard control variables representing individual socio-demographic and ethnic characteristics, which are likely to affect both migration decisions and political preferences, are controlled for. Gender, age, language, education, revenue, and rural place of residence are included in all regressions. In addition, robustness checks control for internet access, using internet as the main source of information, an alternative indicator of ethnicity, having a white collar job and being a farmer. Details of how these variables were constructed and descriptive statistics can be found in Table A3.

\section{Summary Statistics}

Table 1 summarises individual socio-demographic characteristics according to work experience abroad. It shows that individuals who have worked in the West are in a higher proportion Romanian speakers, living in urban areas, with higher education and higher revenues. 
Respondents who have worked in the East are more likely to be men without higher education and living in rural areas. Few individuals who were above 60 at the time of the survey have ever worked abroad.

Table 2 summarises individual geopolitical preferences according to work experience abroad. It indicates that return migrants from the West are significantly more likely to support EU accession, while return migrants from the East are significantly more likely to support CU accession.

Table 1: Socio-demographic characteristics of returnees and non-migrants

\begin{tabular}{|c|c|c|c|c|c|}
\hline & $\begin{array}{l}\text { Non } \\
\text { migrants }\end{array}$ & $\begin{array}{l}\text { Returnees } \\
\text { East }\end{array}$ & $\begin{array}{l}\text { Returnees } \\
\text { West }\end{array}$ & $\begin{array}{l}\text { Returnees } \\
\text { East and } \\
\text { West }\end{array}$ & $\begin{array}{l}\text { Pearson's Chi } \\
\text { Square test of } \\
\text { independence }\end{array}$ \\
\hline Sample size & 904 & 220 & 83 & 30 & \\
\hline Female $(\%)$ & 68.69 & 37.27 & 48.19 & 23.33 & $97.77 * * *$ \\
\hline Revenue (scale 1-12) & 4.87 & 4.98 & 5.67 & 5.52 & $73.39 * * *$ \\
\hline Romanian language (\%) & 74.89 & 77.73 & 85.54 & 93.33 & $10.01 * *$ \\
\hline Age & & & & & $155.12 * * *$ \\
\hline $18-29$ & 16.04 & 22.27 & 20.48 & 13.33 & \\
\hline $30-44$ & 14.93 & 44.09 & 31.33 & 40.00 & \\
\hline $45-59$ & 28.54 & 26.82 & 28.92 & 36.67 & \\
\hline $60+$ & 40.49 & 6.82 & 19.28 & 10.00 & \\
\hline Rural (\%) & 52.65 & 60.00 & 38.55 & 63.33 & $12.58 * * *$ \\
\hline Completed higher education (\%) & 17.37 & 13.18 & 20.48 & 23.33 & 3.93 \\
\hline
\end{tabular}

Note: $* * * p<0.01 ; * * \mathrm{p}<0.05$. Romanian language indicates that the respondent chose to conduct the interview in Romanian. Pearson's Chi Square test rejects the null hypothesis that demographic characteristics and migration experience are independently distributed. 
Table 2: Geopolitical preferences of returnees and non-migrants

\begin{tabular}{|c|c|c|c|c|c|}
\hline & $\begin{array}{c}\text { Non } \\
\text { migrants }\end{array}$ & $\begin{array}{l}\text { Returnees } \\
\text { East }\end{array}$ & $\begin{array}{c}\text { Returnees } \\
\text { West }\end{array}$ & $\begin{array}{c}\text { Returnees } \\
\text { East and } \\
\text { West }\end{array}$ & $\begin{array}{l}\text { Pearson's Chi } \\
\text { Square test of } \\
\text { independence }\end{array}$ \\
\hline Sample size & 904 & 220 & 83 & 30 & \\
\hline EU accession (\%) & & & & & $26.61 * * *$ \\
\hline For & 51.39 & 47.03 & 74.70 & 75.86 & \\
\hline Against & 30.74 & 35.62 & 16.87 & 13.79 & \\
\hline $\begin{array}{r}\text { Do not know or would not } \\
\text { participate }\end{array}$ & 17.87 & 17.35 & 8.43 & 10.34 & \\
\hline CU accession (\%) & & & & & $34.75 * * *$ \\
\hline For & 54.71 & 69.41 & 43.37 & 40.00 & \\
\hline Against & 26.25 & 15.98 & 37.35 & 46.67 & \\
\hline $\begin{array}{r}\text { Do not know or would not } \\
\text { participate }\end{array}$ & 15.17 & 10.05 & 12.05 & 10.00 & \\
\hline
\end{tabular}

Note: $* * * p<0.01$. EU accession and CU accession respectively indicate how the respondent would vote in referendums on European Union and on Customs Union (with Russia, Belarus and Kazakhstan) accession. Pearson's Chi Square test rejects the null hypothesis that geopolitical preferences and migration experience are independently distributed.

As socio-demographic characteristics are correlated with migration experience and they are also likely to affect political preferences, they need to be controlled for when analysing the effects of migration on political opinions.

\section{Regression results: geopolitical preferences and work experience abroad}

This section presents regression results in which geopolitical preferences are predicted by work experience abroad and control variables. As our main measures of geopolitical preferences are dummy variables, we use binary logistic regression to estimate the following model:

$$
P\left(Y_{i}=1\right)=1 /\left[1+\exp \left(-\left(\alpha+\beta X_{i}+\gamma_{E} m_{E}+\gamma_{W} m_{W}+\gamma_{E W} m_{E W}+\varepsilon_{i}\right)\right)\right],
$$

where $Y_{i}$ is a dummy indicating support for EU accession or CU accession, $X_{i}$ is a vector of individual characteristics, $m_{E}, m_{W}, m_{E W}$ are dummies taking the value one if the respondent 
has respectively worked in the East, West and both East and West and $\varepsilon_{i}$ are unobserved individual determinants of political preferences. Additional district-level determinants of geopolitical preferences are controlled for in robustness checks. The coefficients of interest are $\gamma_{E}, \gamma_{W}$ and $\gamma_{E W}$

Section 5.1 presents baseline regressions which do not deal with endogeneity. The identification strategy and instrumental variable results are discussed in section 5.2.

\subsection{Baseline regressions}

Baseline regression coefficients are presented in Table 3. They indicate that respondents who have a working experience in the West are more likely to support EU accession compared to respondents who have never worked abroad. Likewise, return migrants from the East are more likely to support $\mathrm{CU}$ accession. Both coefficients are significant at the $1 \%$ level. The magnitude of these coefficients indicates that having worked in the West multiplies the odds of being in favour of EU accession by a factor of 2.23, and having worked in the East multiplies the odds of being in favour of $\mathrm{CU}$ accession by a factor of 2.03 , everything else being equal.

No significant difference with non-migrants is found for the small category of respondents who have worked in both Eastern and Western destinations. Removing this control category, which is equivalent to merging this group of respondents with the non-migrants, does not affect the coefficients of the other explanatory variables. ${ }^{12}$

Control variables show that younger, more educated and Romanian speaking respondents are significantly more likely to support EU accession. Language has the highest coefficient in terms of size. Being a Romanian speaker multiplies the odds of being in favour

\footnotetext{
${ }^{12}$ Only 30 respondents have worked in both Eastern and Western destinations, as indicated in Table 1. While removing this insignificant control variable does not affect the results, doing so has the advantage of leaving us with only two endogenous variables: Returnee East and Returnee West, and therefore reducing the minimum number of required instruments to 2 .
} 
of EU accession by a factor 5.24 and the odds of being in favour of CU accession by a factor of 0.22 . Gender, revenue and living in a rural area are not correlated with geopolitical preferences. The explanatory variables included in the baseline model are not subject to multicollinearity (Table B11).

Very similar results are obtained when using the five point scale measure of pro-EU preferences as outcome of interest (Table B1). Tables B2 and B3 show regression results with some additional control variables. Having internet access and using internet as the main source of information are strongly associated with supporting EU accession, but they have no effect on supporting CU accession. Being a farmer and having a white collar job are weakly associated with more pro EU attitudes. Support for EU accession is significantly higher among ethnic Moldovans and ethnic Romanians, while support for $\mathrm{CU}$ accession is significantly higher among ethnic Russians. More importantly, the effects of work experience abroad are not altered by the inclusion of these additional controls.

As discussed in Section 3, these regression coefficients cannot be trusted to only capture the causal effects of migration on geopolitical preferences. Self-selection in migration and return decisions are likely to bias these coefficients. If individuals with more Western values are more likely to look for jobs in EU countries, the estimated effect of Western work experience on support for EU accession will be biased upwards. Similarly, the effect of Eastern work experience on support for CU accession will be biased upwards if individuals with proRussian values are more likely to look for jobs in Russia. Although there is extensive evidence indicating that the large majority of Moldovan emigration is economically and not politically motivated, ${ }^{13}$ we cannot rule out the possibility the coefficients are at least partly driven by selfselection on values. In addition, if emigrants with more Western values are less likely to return

\footnotetext{
${ }^{13}$ E.g. Luecke et al. (2007).
} 
to Moldova, the coefficient of work experience in the West will be biased downwards. The return decisions of Moldovan migrants have been shown to depend on socio-demographic, economic and family factors (Pinger 2007, Gorlich and Trebesch, 2008), but no evidence exists on the role of cultural and political factors. In absence of such evidence, we cannot rule out the possibility that regression coefficients are biased by self-selection in return decisions. Estimating the causal effect of work experience abroad thus requires an identification strategy. 
Table 3: Support for European Union and Customs Union accession and work experience abroad.

\begin{tabular}{|c|c|c|c|c|}
\hline & Pro EU & Pro CU & Pro EU & Pro CU \\
\hline \multirow[t]{2}{*}{ Returnee East } & $-0.420 *$ & $0.706^{* * *}$ & $-0.448^{*}$ & 0.733 *** \\
\hline & $(0.234)$ & $(0.186)$ & $(0.231)$ & $(0.176)$ \\
\hline \multirow[t]{2}{*}{ Returnee West } & $0.804 * * *$ & -0.243 & $0.783 * * *$ & -0.222 \\
\hline & $(0.290)$ & $(0.282)$ & $(0.282)$ & $(0.283)$ \\
\hline \multirow[t]{2}{*}{ Returnee East and West } & 0.527 & -0.454 & & \\
\hline & $(0.440)$ & $(0.379)$ & & \\
\hline \multirow[t]{2}{*}{ Higher education } & $0.564 * * *$ & $-0.295 * *$ & $0.568 * * *$ & $-0.300 * *$ \\
\hline & $(0.153)$ & $(0.142)$ & $(0.150)$ & $(0.139)$ \\
\hline \multirow[t]{2}{*}{ Romanian language } & $1.657 * * *$ & $-1.522 * * *$ & $1.666^{* * *}$ & $-1.530 * * *$ \\
\hline & $(0.216)$ & $(0.320)$ & $(0.210)$ & $(0.315)$ \\
\hline \multirow[t]{2}{*}{ Age } & $-0.186 * * *$ & $0.122^{*}$ & $-0.191 * * *$ & $0.127 * *$ \\
\hline & $(0.041)$ & $(0.063)$ & $(0.041)$ & $(0.063)$ \\
\hline \multirow[t]{2}{*}{ Revenue } & 0.014 & -0.027 & 0.015 & -0.027 \\
\hline & $(0.035)$ & $(0.031)$ & $(0.035)$ & $(0.032)$ \\
\hline \multirow[t]{2}{*}{ Female } & -0.045 & -0.169 & -0.070 & -0.144 \\
\hline & $(0.127)$ & $(0.149)$ & $(0.122)$ & $(0.144)$ \\
\hline \multirow[t]{2}{*}{ Rural } & -0.096 & -0.011 & -0.090 & -0.016 \\
\hline & $(0.189)$ & $(0.208)$ & $(0.186)$ & $(0.206)$ \\
\hline \multirow[t]{2}{*}{ Constant } & $-0.745^{* *}$ & $1.330 * * *$ & $-0.712 * *$ & $1.297 * * *$ \\
\hline & $(0.337)$ & $(0.322)$ & $(0.348)$ & $(0.316)$ \\
\hline Chi2 & 250.91 & 137.13 & 252.44 & 132.05 \\
\hline $\mathrm{P}$ & 0.00 & 0.00 & 0.00 & 0.00 \\
\hline$N$ & 1,192 & 1,192 & 1,192 & 1,192 \\
\hline
\end{tabular}

$* p<0.1 ; * * p<0.05 ; * * * p<0.01$. Logistic regressions. Robust standard errors clustered at the district level in parentheses. Returnee East, returnee West and returnee East and West are dummies for work experience in a former Soviet country, a Western country and both former Soviet and Western countries respectively. Pro EU and pro CU are dummies indicating that the respondent would vote in favour of accession to the European Union and Customs Union (with Russia, Belarus and Kazakhstan) respectively. Romanian language indicates that the respondent chose to conduct the interview in Romanian.

\subsection{Instrumental variable regressions}

Our identification strategy consists in instrumenting individual migration with districtlevel migrant networks in Eastern and Western destinations in 2004, or eight years before the 
survey data was collected. ${ }^{14}$ A similar strategy has been used in Batista and Vicente (2011).

Networks abroad remove several barriers to migration. First, they reduce risk and uncertainty by providing information on jobs, prices, housing and administrative rules at the destination. Second, they may alleviate credit constraints by sending remittances. Third, they may reduce administrative barriers to migration for close family members. Finally, when the economic benefits of migration are visible to others, they may increase the incentives to emigrate, even for individuals who do not have friends or family abroad. ${ }^{15}$ Based on these arguments, we hypothesise that the probability of having a work experience in a foreign destination increases with the density of migrant networks in that destination. We expect a stronger effect for Western networks than for Eastern networks because migration to Western countries is subject to stronger financial, administrative and informational constraints.

District-level data on the number of persons living abroad by country of destination is taken from the 2004 population census. We distinguish between Eastern and Western destinations using the same geographic criterion as for the individual migration. In order to measure the density of migrant networks in each destination, we divide the number of migrants from each district in that destination by the district population. We thus construct two variables: district diaspora West (2004) and district diaspora East (2004). These variables will serve as instruments for the two endogenous explanatory variables of interest, returnee East and returnee West. Note that with only two instruments, we cannot estimate a separate causal effect

\footnotetext{
${ }^{14}$ Some authors have used historic determinants of migration patterns as an instrument for migration. Such an identification strategy is unlikely to be suitable for this research, because most historic factors which affect migration are also likely to affect geo-political preferences. For example, the 1998 financial and economic crisis in Russia, which has driven the first massive outflows of labor to EU destinations, is likely to also have decreased support for closer economic ties with Russia. Indeed, cooperation with a country in crisis, with a falling currency and falling imports, is less attractive. Likewise, cultural ties with Romania have driven migration flows to Romania, as well as to Italy, France and Portugal, whose languages are easy to learn for Romanian speakers. The same cultural ties are likely to increase support for EU accession.

${ }^{15} \mathrm{~A}$ number of papers have shown that relative income deprivation, i.e. the disutility experienced when individuals from one's reference group enjoy higher standards of living, is a significant driver of emigration (e.g; Stark et al., 2009).
} 
for the dummy variable returnee East and West. This is a minor limitation, as the group of respondents who have worked in both Eastern and Western destinations only represents 30 out of 1237 observations, and this particular treatment, which did not show any robust effects in baseline regressions, is not a major point of interest for this paper. Baseline regressions have shown that including this treatment or leaving it out has no effect on the coefficients of other variables, therefore we drop this treatment from the IV regressions. ${ }^{16}$

First stage regression results are presented in Table C1. Both instruments are highly significant, with the expected sign, thus the first condition for the validity of instruments is satisfied. As expected, the order of magnitude is several times higher for the Western diaspora coefficient than for the Eastern diaspora coefficient. Education is not a significant predictor of being a return migrant. This could be because education does not significantly affect temporary migration decisions. ${ }^{17}$ Alternatively, it could be because education has opposite effects on the decision to migrate and the decision to return, which cancel each other out. ${ }^{18}$

The second condition for the validity of instruments, i.e. the lack of correlation of the instruments with the error term, cannot formally be tested because the model is just identified. It is however possible to discuss the plausibility of this condition using theoretical arguments and additional robustness checks. Several possible issues with the validity of the two instruments come to mind. The first one is the possibility that migrant networks affect the economy at the district level, for example through labour or local market effects, which may have consequences on individual geopolitical preferences. In other words, diaspora networks might not be a valid instrument if they are correlated with omitted variables representing

\footnotetext{
${ }^{16}$ The respective observations remain included in the sample, thus the control group includes 904 individuals who have never worked abroad and 30 individuals who have worked in both Eastern and Western destinations.

${ }^{17}$ As mentioned in the introduction, brain waste is relatively common among Moldovans working abroad. Returns to migration are therefore not necessarily higher for skilled individuals.

${ }^{18}$ It could for instance be the case that more educated individuals are more likely to migrate, but also less likely to return. The effect of education on return probabilities is not clear cut. Pinger (2007) for example finds that tertiary education has a positive effect on the return probability, but she also finds that individuals working in the agriculture and construction sector, who are on average less skilled, are more likely to return.
} 
district-level economic factors. In order to check whether this may be an issue, we included district-level indicators of economic activity among the explanatory variables in baseline regressions. Results indicate that district-level economic indicators are not correlated with geopolitical preferences, thus they are unlikely to represent a significant omitted variable (Table B4).

A second possible concern could be that the demographic or ethnic distribution of the population in districts is correlated with both migration patterns and geopolitical preferences. Tables B5 and B6 show that the ethnic and demographic composition of the district does not affect individual foreign policy preferences, once individual socio-demographic characteristics are controlled for. ${ }^{19}$

A third potential issue could be that individuals living in districts bordering Romania are more likely to have worked in the West because the cost of Western migration is lower for them, and more likely to support EU accession because the benefits of open borders with the EU are higher for them. To test for this possibility, we included a dummy for living in a district bordering Romania among the explanatory variables. We have estimated the coefficient of this dummy first for the entire sample and second for the sample of non-migrants only. The results, presented in Table B10, show that living in a district bordering Romania is not a significant driver of support for EU accession once individual socio-demographic characteristics are controlled for.

Finally, diaspora networks could affect individual geopolitical opinions not only by affecting individual migration, but also by spreading relevant information at the district level.

\footnotetext{
19 Table B5 also indicates that individuals living in districts where the Gagauz ethnic group is more present are less likely to support EU accession. This is in line with the results of the 2014 referendum conducted in Gagauzia, an autonomous region populated by a majority of Gagauz individuals, where the large majority of voters rejected EU accession and supported CU accession. This region is excluded from the survey, so the coefficient is driven by the variation in Gagauz populations and pro-EU opinions in other districts.
} 
Such local diffusion of migrants' political ideas has been documented in several studies (PerezArmendariz and Crow, 2010; Batista and Vicente, 2011; Pfutze, 2012; Chauvet and Mercier, 2014; Barsbai et al., 2017). In order to check whether this may be a concern, we constructed a measure of geopolitical preferences in respondents' district and checked whether it is correlated with the individual geopolitical preferences. ${ }^{20} \mathrm{We}$ have tested the effect of district-level geopolitical preferences both on the whole sample, and on the sample of individuals who have never migrated. The results presented in Table B7 indicate that geopolitical preferences in the district are not significant predictors of individual geopolitical preferences. In one specification only is the district average significant at the $10 \%$ level. These tests suggest that district-level migrant networks are valid instruments for the individual work experience abroad. As an additional robustness check however, we will control for district-level geopolitical preferences in IV regressions.

The result that geopolitical preferences at the district level are not significant predictors of individual geopolitical preferences, both for return migrants and for non-migrants, may seem to contradict some previous studies which have shown that migration entails political spill-over effects at the local level. The most plausible explanation for this apparent contradiction is that political spill-over effects are geographically limited. We measure such effects at the district level, dividing Moldova into 35 relatively big administrative units, while studies which have found spill-over effects focused on smaller geographical units. For instance, Barsbai et al. (2017) measure such effects at the locality level in Moldova, dividing the country into 800 (much smaller) administrative units; Pfutze (2012) and Mercier (2014) use locality level data; Batista and Vicente (2011) use community-level data and Perez-Armendariz and Crow (2010) measure spillovers in restricted circles of friends and family.

\footnotetext{
${ }^{20}$ The measure is constructed as the average EU versus CU scale in respondent's district, excluding respondent's own observation.
} 
Table 4 presents second stage regression results, where the probabilities of having worked in the West and East predicted in first stage regressions are included instead of the original migration variables. An interesting result emerges. Work experience in the East loses significance for predicting geopolitical preferences, while work experience in the West remains significant, with the expected signs. Robustness checks indicate that these results hold when controlling for district-level geopolitical preferences (Table B8) and when using the five-point scale EU versus CU measure as the outcome of interest (Table 5, column 3 and Table B9). ${ }^{21}$ These results are consistent with the two theoretical mechanisms discussed in Section 3, both of which predict stronger effects for Western migration on pro-EU preferences. These findings are also consistent with the results of Barsbai et al (2017), who find that the share of votes for the Communist party in Moldova are strongly negatively affected by Western emigration, but only weakly affected by Eastern emigration.

\footnotetext{
${ }^{21}$ The coefficients for the two stage linear regression model in Table 5, column 3 were estimated by replacing the original migration variables with the estimated probability of being a returnee from the first stage regression. The coefficients in Table B9 were estimated using STATA's ivregress command for linear models with endogenous variables.
} 
Table 4: Support for European Union and Customs Union accession and work experience abroad (IV second stage)

\begin{tabular}{|c|c|c|c|}
\hline & $\begin{array}{l}\text { Pro EU } \\
\text { (IV logit) }\end{array}$ & $\begin{array}{l}\text { Pro CU } \\
\text { (IV logit) }\end{array}$ & $\begin{array}{c}\text { EU versus CU } \\
\text { (2SLS) }\end{array}$ \\
\hline \multirow[t]{2}{*}{ Returnee East IV } & -0.614 & -1.746 & 0.251 \\
\hline & $(0.987)$ & (1.349) & $(0.751)$ \\
\hline \multirow[t]{2}{*}{ Returnee West IV } & $5.703 * *$ & $-5.167 * *$ & $4.211 * * *$ \\
\hline & $(2.543)$ & $(2.604)$ & $(1.409)$ \\
\hline \multirow[t]{2}{*}{ Higher education } & $0.627 * * *$ & $-0.479 * * *$ & $0.406^{* * *}$ \\
\hline & $(0.144)$ & $(0.159)$ & $(0.097)$ \\
\hline \multirow[t]{2}{*}{ Romanian language } & $1.426 * * *$ & $-1.370 * * *$ & $1.099 * * *$ \\
\hline & $(0.242)$ & $(0.307)$ & $(0.195)$ \\
\hline \multirow[t]{2}{*}{ Age } & $-0.172 *$ & -0.144 & -0.012 \\
\hline & $(0.097)$ & $(0.160)$ & $(0.082)$ \\
\hline \multirow[t]{2}{*}{ Revenue } & -0.017 & -0.017 & 0.004 \\
\hline & $(0.038)$ & $(0.039)$ & $(0.026)$ \\
\hline \multirow[t]{2}{*}{ Female } & 0.004 & $-0.694 * *$ & 0.209 \\
\hline & $(0.239)$ & $(0.347)$ & $(0.186)$ \\
\hline \multirow[t]{2}{*}{ Rural } & 0.125 & -0.127 & 0.136 \\
\hline & $(0.185)$ & $(0.218)$ & $(0.139)$ \\
\hline \multirow[t]{2}{*}{ Constant } & -0.873 & $3.048 * * *$ & 0.508 \\
\hline & $(0.589)$ & $(0.953)$ & $(0.519)$ \\
\hline Chi2 & 250.65 & 101.25 & . \\
\hline $\mathrm{P}$ & 0.00 & 0.00 & . \\
\hline R-squared & & & 0.16 \\
\hline$N$ & 1,192 & 1,192 & 1,186 \\
\hline
\end{tabular}

$* p<0.1 ; * * p<0.05 ; * * * p<0.01$. Robust standard errors clustered at the district level in parentheses. Returnee East IV and returnee West IV are predicted probabilities to have worked in a former Soviet country and in a Western country respectively (first stage regressions in Table $\mathrm{C} 1$ ). Pro EU and pro CU are dummies indicating that the respondent would vote in favour of accession to the European Union and Customs Union (with Russia, Belarus and Kazakhstan) respectively. EU versus $\mathrm{CU}$ is a five point measure indicating respondents' position on the pro CU-pro EU preference spectrum, with higher values indicating stronger pro-European preferences. Romanian language indicates that the respondent chose to conduct the interview in Romanian.

As an attempt to further investigate the extent to which the theoretical mechanisms discussed in Section 3 are driving these results, respondents' opinions on the most important benefits of joining the EU and the CU were analysed. Tables D1 and D2 show the distribution of answers. 
In the case of EU accession, the most frequently mentioned benefits are "visa liberalisation', 'I do not know' and 'there are no benefits'. Consistent with the first theoretical mechanism (information-induced change in policy preferences), return migrants from the West are less likely to believe that there are no benefits ( $14.5 \%$ of them do so compared to $23.1 \%$ for non-migrants) or to state that they do not know what the benefits are $(9.6 \%$ of them do so compared to $24.8 \%$ for non-migrants). Consistent with the second theoretical mechanism (payoff-induced change in policy preferences), return migrants from the West are more likely to state that visa liberalisation is an important benefit of joining the EU ( $26.5 \%$ of them do so, compared to $17.1 \%$ for non-migrants).

In the case of $\mathrm{CU}$ accession, the most frequent responses are 'cheaper energy', 'I do not know' and 'there are no benefits'. Cheaper energy is the main perceived benefit of CU accession and there is no obvious reason why return migrants from Russia should attach a higher value to this privilege. The answer is indeed chosen with a similar frequency by returnees from the East and non-migrants. Return migrants from the East are less likely to believe that there are no benefits of joining the $\mathrm{CU}$ (10\% compared to $15 \%$ for non-migrants) and that they do not know what the benefits are (16\% compared to $27 \%$ for non-migrants), consistent with the hypothesis that migration leads to new information, but differences with non-migrants are smaller than in the case of Western migration, consistent with the hypothesis that information shocks are higher for Western destinations.

These answer distributions are consistent with the idea that work experience in the West increases support for EU accession both because it improves information about the EU and because it increases the value attached to free labour mobility with the EU. They also suggest that work experience in the East provides a smaller amount of new information about the $\mathrm{CU}$ and that it does not increase the value attached to low energy prices, the main perceived benefit of CU accession. 


\section{Conclusion}

Does working abroad affect migrants' political preferences? In destination countries, migrants are exposed to new information through interactions with different cultures, media, institutions, policies and social norms. Such exposure may change some of the values and beliefs on which political preferences are based. In addition, working abroad may change migrants' economic payoff from certain policies, and consequently shift their position in some dimensions of the political spectrum. This paper investigated such effects for temporary labour migrants from Moldova, focusing on the support for European integration versus closer ties with Russia, a central question in political debates since the country's independence.

We have shown that work experience in Western countries increases support for European integration and decreases support for closer ties with Russia. Work experience in Russia and other Eastern countries on the other hand showed no causal impact on individual geopolitical preferences.

The observed asymmetry in the effects of Western and Eastern migration may have two explanations. The first one is information-related. The amount of new information to which Moldovan migrants are exposed is likely to be more important in Western countries than in Eastern countries, due to the legacy of communism on economic systems, institutions and values. The second explanation is policy-related. At the time of the survey, migration barriers were significantly higher for the EU than for Russia: a visa was necessary to enter the EU, while that was not the case for Russia. The removal of labour mobility barriers to the EU was the most frequently mentioned reason for supporting EU integration. Work experience in the West is likely to increase the individual valuation of unconstrained mobility to European countries, which may explain why return migrants show higher support for EU accession. On the other hand, the most frequently mentioned reason for supporting closer ties with Russia were lower 
energy prices. There is no particular reason why work experience in Russia should increase the individual valuation of lower energy prices, which may explain why it does not increase support for closer ties with Russia.

The empirical findings of this paper suggest that migration policy can be an effective tool for the European Union to influence attitudes towards the European project in neighbouring countries. Allocating a number of temporary labour migration permits, may, under certain conditions, lead to win-win-win situations, whereby migrants gain higher incomes (and possibly new business ideas and skills), destination countries reduce their labour shortages (and possibly expenditures on aid aimed at poverty reduction), and some core European values and world views (or at least more positive attitudes toward the European Union), spill over to neighbouring countries. Such political externalities of labour migration should not be neglected, particularly in times where international cooperation is needed for dealing with the social, environmental, technological and political challenges facing the world.

This paper and previous research conducted on migration, democracy and political activism show that living abroad shifts the political attitudes of migrants in a direction which is closer to the political attitudes and norms in destination countries. In the same time, heated debates on the (lack of) integration and acculturation of certain migrant communities, as well as some electoral results (the overwhelming support for Recep Tayyip Erdogan in Belgium and Germany in the 2018 election is one example) point out that this is not a systematic phenomenon. More research is necessary in order to understand what type of world views are likely to be adopted by migrants in destination countries and which factors favour or hinder this process. In particular, it is necessary to understand the role played by the duration of stay, the age at the moment of migrating, the cultural distance between origin and destination countries, and migrants' rights and obligations in destination countries. Such evidence-based insights can improve the design of migration policies by clarifying their multi-dimensional trade-offs. 


\section{Appendix A: Variables definitions and descriptive statistics}

Table A1

Work experience abroad

\begin{tabular}{|c|c|c|c|c|c|c|c|}
\hline Variable & Type & $\begin{array}{l}\text { Survey } \\
\text { Question }\end{array}$ & Answer coding & Mean & Std.dev. & Min & $\operatorname{Max}$ \\
\hline $\begin{array}{l}\text { Returnee } \\
\text { East }\end{array}$ & Dummy & \multirow{4}{*}{$\begin{array}{l}\text { Have you } \\
\text { ever } \\
\text { worked } \\
\text { abroad after } \\
1991 ?\end{array}$} & $\begin{array}{l}\text { Russia, Ukraine, Belarus, } \\
\text { Kazakhstan, Turkmenistan } \rightarrow 1\end{array}$ & 0.18 & 0.38 & 0 & 1 \\
\hline & & & $\begin{array}{l}\text { No experience or other } \\
\text { countries } \rightarrow 0\end{array}$ & & & & \\
\hline $\begin{array}{l}\text { Returnee } \\
\text { West }\end{array}$ & Dummy & & $\begin{array}{l}\text { Romania, Italy, France, Germany, } \\
\text { UK, USA, Greece, Holland, } \\
\text { Portugal, Spain, Czech Republic, } \\
\text { Lithuania, New Zealand, Belgium, } \\
\text { Canada, Ireland, Poland, Austria, } \\
\text { Croatia, Sweden, Australia, } \\
\text { Hungary, } \rightarrow 1\end{array}$ & 0.07 & 0.25 & 0 & 1 \\
\hline & & & $\begin{array}{l}\text { No experience or other } \\
\text { countries } \rightarrow 0\end{array}$ & & & & \\
\hline $\begin{array}{l}\text { Returnee } \\
\text { East and } \\
\text { West }\end{array}$ & Dummy & & $\begin{array}{l}\text { Work in experience at least one } \\
\text { Eastern and one Western } \\
\text { country } \rightarrow 1\end{array}$ & 0.02 & 0.15 & 0 & 1 \\
\hline
\end{tabular}

Note: work experience in Turkey (10 observations), Israel (8 observations) were kept in the sample, but they were not classified in either category. Barsbai et al (forthcoming) classify Israel as a Western destination and Turkey as an Eastern destination, based on their Polity IV scores. Given the low number of observations in these two categories, results would not be affected if we followed the same classification. 
Table A2

Geopolitical preferences

\begin{tabular}{|c|c|c|c|c|c|c|c|}
\hline $\begin{array}{l}\text { Variable } \\
\text { name }\end{array}$ & Type & Survey Question & Answer coding & Mean* & Std.dev* & Min & Max \\
\hline Pro EU & Dummy & $\begin{array}{l}\text { If next Sunday there } \\
\text { was a referendum } \\
\text { regarding Moldova's } \\
\text { European Union } \\
\text { accession, what would } \\
\text { be your vote? }\end{array}$ & $\begin{array}{l}\text { Yes } \rightarrow 1 \\
\text { No, I do not know } \\
\text { or and I would not } \\
\text { participate } \rightarrow 0\end{array}$ & 0.53 & 0.50 & 0 & 1 \\
\hline Pro CU & Dummy & $\begin{array}{l}\text { If next Sunday there } \\
\text { was a referendum } \\
\text { regarding Moldova's } \\
\text { Customs Union } \\
\text { accession, what would } \\
\text { be your vote? }\end{array}$ & $\begin{array}{l}\text { Yes } \rightarrow 1 \\
\text { No, I do not know } \\
\text { or and I would not } \\
\text { participate } \rightarrow 0\end{array}$ & 0.56 & 0.50 & 0 & 1 \\
\hline \multirow[t]{4}{*}{$\begin{array}{l}\text { EU versus } \\
\text { CU }\end{array}$} & $\begin{array}{l}\text { Scale 0- } \\
4\end{array}$ & $\begin{array}{l}\text { If next Sunday there } \\
\text { was a referendum } \\
\text { regarding Moldova's } \\
\text { European Union } \\
\text { accession, what would } \\
\text { be your vote? }\end{array}$ & $\begin{array}{l}\text { Pro CU and against } \\
\text { EU } \rightarrow 0 \\
\text { pro } \mathrm{CU} \text { and } \\
\text { undecided about } \\
\text { EU } \rightarrow 1\end{array}$ & 0.09 & 0.01 & 0 & 4 \\
\hline & & $\begin{array}{l}\text { If next Sunday there } \\
\text { was a referendum } \\
\text { regarding Moldova's }\end{array}$ & $\begin{array}{l}\text { pro CU and pro } \\
E U \rightarrow 2\end{array}$ & 0.32 & 0.01 & & \\
\hline & & $\begin{array}{l}\text { Customs Union } \\
\text { accession, what would } \\
\text { be your vote? }\end{array}$ & $\begin{array}{l}\text { undecided about } \\
\mathrm{CU} \text { and pro } \mathrm{EU} \rightarrow 3\end{array}$ & 0.10 & 0.01 & & \\
\hline & & & $\begin{array}{l}\text { against } \mathrm{CU} \text { and pro } \\
\text { EU } \rightarrow 4\end{array}$ & 0.23 & 0.01 & & \\
\hline
\end{tabular}

*For the categorical variable EU versus $\mathrm{CU}$, the proportion and standard error of each response category are shown. 
Table A3

Socio-demographic characteristics

\begin{tabular}{|c|c|c|c|c|c|c|}
\hline Variable & Definition & Type & Mean* & Std.dev. & Min & Max \\
\hline Romanian & interview is conducted in Romanian & dummy & 0,77 & 0,42 & 0 & 1 \\
\hline Female & respondent is a woman & dummy & 0,61 & 0,49 & 0 & 1 \\
\hline \multirow[t]{5}{*}{ Age } & age group & Scale (1-4) & & & 1 & 4 \\
\hline & $18-29$ & & 0.17 & & & \\
\hline & $30-44$ & & 0.22 & & & \\
\hline & $45-59$ & & 0.28 & & & \\
\hline & $60+$ & & 0.32 & & & \\
\hline Age & age group & Scale (1-4) & 2,76 & 1,09 & 1 & 4 \\
\hline Revenue** & revenue group & Scale (1-12) & 4,95 & 2,27 & 1 & 12 \\
\hline Higher education & completed higher education & dummy & 0,17 & 0,38 & 0 & 1 \\
\hline Rural & lives in a rural area & dummy & 0,53 & 0,50 & 0 & 1 \\
\hline Internet access & has internet access & dummy & 0,41 & 0,49 & 0 & 1 \\
\hline Internet information & internet is the main source of information & dummy & 0,11 & 0,31 & 0 & 1 \\
\hline White collar & white collar job & dummy & 0,14 & 0,34 & 0 & 1 \\
\hline Farmer & works in farming sector & dummy & 0,14 & 0,34 & 0 & 1 \\
\hline
\end{tabular}


Table A4

District level population and ethnic composition.

\begin{tabular}{|c|c|c|c|c|c|c|c|}
\hline District & $\begin{array}{c}\text { Populatio } \\
n\end{array}$ & $\begin{array}{c}\text { Moldovans } \\
\%\end{array}$ & $\begin{array}{c}\text { Ucranians } \\
\%\end{array}$ & $\begin{array}{l}\text { Russians } \\
\%\end{array}$ & $\begin{array}{l}\text { Gagauz } \\
\%\end{array}$ & $\begin{array}{l}\text { Romanians } \\
\%\end{array}$ & $\begin{array}{l}\text { Bulgarians } \\
\%\end{array}$ \\
\hline Chisinau & 712218 & 67,6 & 8,3 & 13,9 & 0,9 & 4,5 & 1,2 \\
\hline Balti & 127561 & 52,4 & 23,7 & 19,2 & 0,2 & 1,8 & 0,2 \\
\hline $\begin{array}{l}\text { Anenii Noi } \\
\text { Basarabeasc }\end{array}$ & 81710 & 84,2 & 8,0 & 5,1 & 0,3 & 1,0 & 0,6 \\
\hline $\mathrm{a}$ & 28978 & 69,8 & 6,7 & 8,9 & 7,7 & 0,2 & 5,3 \\
\hline Briceni & 78027 & 70,6 & 25,6 & 2,6 & 0,1 & 0,4 & 0,1 \\
\hline Cahul & 119231 & 76,3 & 6,6 & 6,5 & 3,1 & 1,8 & 4,9 \\
\hline Cantemir & 60001 & 88,3 & 1,6 & 1,2 & 0,9 & 1,5 & 6,2 \\
\hline Calarasi & 75075 & 92,2 & 3,7 & 1,3 & 0,1 & 2,0 & 0,1 \\
\hline Causeni & 90612 & 87,7 & 2,7 & 4,2 & 0,7 & 3,1 & 1,2 \\
\hline Cimislia & 60925 & 86,9 & 5,5 & 3,9 & 0,5 & 0,5 & 2,2 \\
\hline Criuleni & 72254 & 92,8 & 3,7 & 1,4 & 0,1 & 1,6 & 0,1 \\
\hline Donduseni & 46442 & 80,3 & 12,7 & 5,8 & 0,1 & 0,5 & 0,1 \\
\hline Drochia & 87092 & 85,4 & 11,3 & 1,9 & 0,1 & 0,8 & 0,0 \\
\hline Dubasari & 34015 & 96,0 & 1,5 & 1,8 & 0,1 & 0,3 & 0,0 \\
\hline Edinet & 81390 & 72,2 & 19,8 & 6,2 & 0,2 & 0,5 & 0,1 \\
\hline Falesti & 90320 & 84,0 & 11,9 & 3,4 & 0,0 & 0,3 & 0,0 \\
\hline Floresti & 89389 & 84,8 & 9,0 & 5,2 & 0,1 & 0,5 & 0,1 \\
\hline Glodeni & 60975 & 76,0 & 19,5 & 2,8 & 0,1 & 0,5 & 0,1 \\
\hline Hincesti & 119762 & 90,3 & 5,2 & 1,2 & 0,1 & 2,5 & 0,2 \\
\hline Ialoveni & 97704 & 93,5 & 1,1 & 1,1 & 0,1 & 2,7 & 1,0 \\
\hline Leova & 51056 & 85,5 & 2,4 & 2,3 & 0,8 & 0,9 & 7,5 \\
\hline Nisporeni & 64924 & 93,6 & 0,3 & 0,5 & 0,0 & 3,6 & 0,0 \\
\hline Ocnita & 56510 & 57,5 & 30,7 & 4,9 & 0,1 & 0,2 & 0,1 \\
\hline Orhei & 116271 & 86,4 & 3,9 & 1,9 & 0,1 & 7,1 & 0,1 \\
\hline Rezina & 48105 & 93,0 & 3,5 & 2,3 & 0,1 & 0,8 & 0,1 \\
\hline Riscani & 69454 & 72,6 & 22,5 & 2,5 & 0,1 & 1,1 & 0,1 \\
\hline Singerei & 87153 & 85,1 & 9,7 & 3,5 & 0,1 & 1,3 & 0,0 \\
\hline Soroca & 94986 & 89,2 & 5,0 & 2,7 & 0,1 & 1,0 & 0,1 \\
\hline Straseni & 88900 & 93,8 & 1,1 & 1,8 & 0,1 & 2,9 & 0,1 \\
\hline Soldanesti & 42227 & 95,6 & 2,5 & 0,9 & 0,0 & 0,7 & 0,0 \\
\hline Stefan Voda & 70594 & 92,5 & 3,1 & 2,7 & 0,1 & 0,8 & 0,2 \\
\hline Taraclia & 43154 & 13,9 & 6,1 & 5,0 & 8,3 & 0,1 & 65,6 \\
\hline Telenesti & 70126 & 96,0 & 1,3 & 0,8 & 0,0 & 1,8 & 0,0 \\
\hline Ungheni & 110545 & 88,5 & 7,0 & 2,5 & 0,1 & 1,5 & 0,1 \\
\hline
\end{tabular}




\section{Appendix B: Additional regressions and robustness checks}

Table B1

Position on the pro CU-pro EU preference spectrum and work experience abroad.

\begin{tabular}{|c|c|c|c|c|}
\hline \multirow[b]{2}{*}{ Returnee East } & \multicolumn{4}{|c|}{ EU versus CU } \\
\hline & $\begin{array}{l}-0.459 * * * \\
(0.143)\end{array}$ & & & $\begin{array}{l}-0.487 * * * \\
(0.138)\end{array}$ \\
\hline Returnee West & $\begin{array}{l}0.364 * * * \\
(0.100)\end{array}$ & $\begin{array}{l}0.467 * * * \\
(0.103)\end{array}$ & & $\begin{array}{l}0.340 * * * \\
(0.097)\end{array}$ \\
\hline $\begin{array}{l}\text { Returnee East and } \\
\text { West }\end{array}$ & $0.531 * *$ & $0.667 * * *$ & $0.628 * * *$ & \\
\hline & $(0.214)$ & $(0.208)$ & $(0.206)$ & \\
\hline Higher education & $\begin{array}{l}0.312 * * * \\
(0.096)\end{array}$ & $\begin{array}{l}0.330 * * * \\
(0.090)\end{array}$ & $\begin{array}{l}0.323 * * * \\
(0.090)\end{array}$ & $\begin{array}{l}0.318 * * * \\
(0.094)\end{array}$ \\
\hline Romanian language & $\begin{array}{l}1.240 * * * \\
(0.186)\end{array}$ & $\begin{array}{l}1.246 * * * \\
(0.190)\end{array}$ & $\begin{array}{l}1.268 * * * \\
(0.192)\end{array}$ & $\begin{array}{l}1.250 \text { *** } \\
(0.180)\end{array}$ \\
\hline Age & $\begin{array}{l}-0.105 * * * \\
(0.036)\end{array}$ & $\begin{array}{l}-0.059 * \\
(0.033)\end{array}$ & $\begin{array}{l}-0.063 * \\
(0.032)\end{array}$ & $\begin{array}{l}-0.109 * * * \\
(0.036)\end{array}$ \\
\hline Revenue & $\begin{array}{c}0.019 \\
(0.021)\end{array}$ & $\begin{array}{c}0.023 \\
(0.021)\end{array}$ & $\begin{array}{c}0.026 \\
(0.021)\end{array}$ & $\begin{array}{c}0.021 \\
(0.022)\end{array}$ \\
\hline Female & $\begin{array}{c}0.020 \\
(0.098)\end{array}$ & $\begin{array}{c}0.109 \\
(0.084)\end{array}$ & $\begin{array}{c}0.098 \\
(0.083)\end{array}$ & $\begin{array}{l}-0.006 \\
(0.093)\end{array}$ \\
\hline Rural & $\begin{array}{c}0.000 \\
(0.139)\end{array}$ & $\begin{array}{l}-0.016 \\
(0.147)\end{array}$ & $\begin{array}{l}-0.035 \\
(0.147)\end{array}$ & $\begin{array}{c}0.006 \\
(0.137)\end{array}$ \\
\hline Constant & $\begin{array}{l}1.137 * * * \\
(0.205)\end{array}$ & $\begin{array}{l}0.848 * * * \\
(0.168)\end{array}$ & $\begin{array}{l}0.874 * * * \\
(0.167)\end{array}$ & $\begin{array}{l}1.168 * * * \\
(0.206)\end{array}$ \\
\hline$R^{2}$ & 0.17 & 0.16 & 0.15 & 0.17 \\
\hline$N$ & 1,186 & 1,186 & 1,186 & 1,186 \\
\hline
\end{tabular}

$* p<0.1$; ** $p<0.05$; *** $p<0.01$; OLS regressions. Robust standard errors clustered at the district level in parentheses. EU versus CU is a five point measure indicating respondents' position on the pro Customs Union-pro European Union spectrum. Returnee East and returnee West are dummies for work experience in a former Soviet country and a Western country respectively. Romanian language indicates that the respondent chose to conduct the interview in Romanian. Results are very similar if ordered logit is used instead. 
Table B2

Support for European Union and Customs Union accession and work experience abroad including job type and information source as additional control variables. ${ }^{22}$

\begin{tabular}{|c|c|c|c|c|c|c|}
\hline & Pro EU & Pro CU & Pro CU & Pro EU & Pro EU & Pro CU \\
\hline \multirow[t]{2}{*}{ Returnee East } & $-0.452 * *$ & $0.733 * * *$ & $0.722 * * *$ & $-0.438 * *$ & $-0.438 * *$ & $0.722 * * *$ \\
\hline & $(0.225)$ & $(0.175)$ & $(0.173)$ & $(0.221)$ & $(0.221)$ & $(0.173)$ \\
\hline \multirow[t]{2}{*}{ Returnee West } & $0.743 * *$ & -0.221 & -0.231 & $0.752 * * *$ & $0.752 * * *$ & -0.231 \\
\hline & $(0.292)$ & $(0.279)$ & $(0.279)$ & $(0.288)$ & $(0.288)$ & $(0.279)$ \\
\hline \multirow{2}{*}{ Higher education } & $0.475 * * *$ & $-0.281 *$ & -0.194 & $0.368 * *$ & $0.368 * *$ & -0.194 \\
\hline & $(0.161)$ & $(0.152)$ & $(0.150)$ & $(0.155)$ & $(0.155)$ & $(0.150)$ \\
\hline \multirow[t]{2}{*}{ Romanian language } & $1.685 * * *$ & $-1.524 * * *$ & $-1.526^{* * *}$ & $1.691 * * *$ & $1.691 * * *$ & - \\
\hline & $(0.215)$ & $(0.318)$ & $(0.307)$ & $(0.209)$ & $(0.209)$ & $\begin{array}{r}1.526 * * * \\
(0.307)\end{array}$ \\
\hline \multirow[t]{2}{*}{ Age } & $-0.120 * * *$ & 0.115 & 0.116 & $-0.119 * * *$ & - & 0.116 \\
\hline & $(0.045)$ & $(0.073)$ & $(0.073)$ & $(0.045)$ & $\begin{array}{r}0.119 * * * \\
(0.045)\end{array}$ & $(0.073)$ \\
\hline \multirow[t]{2}{*}{ Revenue } & -0.005 & -0.026 & -0.017 & -0.017 & -0.017 & -0.017 \\
\hline & $(0.037)$ & $(0.034)$ & $(0.035)$ & $(0.039)$ & $(0.039)$ & $(0.035)$ \\
\hline \multirow[t]{2}{*}{ Female } & -0.057 & -0.148 & -0.154 & -0.048 & -0.048 & -0.154 \\
\hline & $(0.118)$ & $(0.141)$ & $(0.140)$ & $(0.120)$ & $(0.120)$ & $(0.140)$ \\
\hline \multirow[t]{2}{*}{ Rural } & -0.040 & -0.026 & -0.018 & -0.049 & -0.049 & -0.018 \\
\hline & $(0.182)$ & $(0.196)$ & $(0.196)$ & $(0.184)$ & $(0.184)$ & (0.196) \\
\hline \multirow[t]{2}{*}{ Internet access } & $0.231 * *$ & 0.033 & 0.055 & $0.206^{*}$ & $0.206^{*}$ & 0.055 \\
\hline & $(0.118)$ & $(0.168)$ & $(0.170)$ & $(0.118)$ & $(0.118)$ & $(0.170)$ \\
\hline \multirow{2}{*}{ Internet information } & $0.477 * *$ & -0.204 & -0.191 & $0.467 * *$ & $0.467 * *$ & -0.191 \\
\hline & $(0.225)$ & $(0.208)$ & $(0.209)$ & $(0.232)$ & $(0.232)$ & (0.209) \\
\hline \multirow[t]{2}{*}{ Farmer } & & & -0.307 & $0.402 *$ & & \\
\hline & & & $(0.207)$ & $(0.226)$ & & \\
\hline \multirow[t]{2}{*}{ White collar } & & & & & $0.402^{*}$ & -0.307 \\
\hline & & & & & $(0.226)$ & (0.207) \\
\hline \multirow[t]{2}{*}{ Constant } & $-0.981 * * *$ & $1.332 * * *$ & $1.303 * * *$ & $-0.953 * * *$ & - & $1.303 * * *$ \\
\hline & & & & & $0.953 * * *$ & \\
\hline Chi2 & $\begin{array}{l}(0.353) \\
300.60\end{array}$ & $\begin{array}{l}(0.353) \\
146.44\end{array}$ & $\begin{array}{l}(0.357) \\
257.73\end{array}$ & $\begin{array}{l}(0.356) \\
311.99\end{array}$ & $\begin{array}{l}(0.350) \\
311.99\end{array}$ & $\begin{array}{r}(0.357) \\
257.73\end{array}$ \\
\hline $\mathrm{P}$ & 0.00 & 0.00 & 0.00 & 0.00 & 0.00 & 0.00 \\
\hline$N$ & 1,192 & 1,192 & 1,192 & 1,192 & 1,192 & 1,192 \\
\hline
\end{tabular}

$* p<0.1$; ** $p<0.05 ; * * * p<0.01$. Logistic regressions. Robust standard errors clustered at the district level in parentheses. Returnee East and returnee West are dummies for work experience in a former Soviet country and a Western country respectively. Pro EU and pro CU are dummies indicating that the respondent would vote in favour of accession to the European Union and Customs Union (with Russia, Belarus and Kazakhstan) respectively. Romanian language indicates that the respondent chose to conduct the interview in Romanian. Internet access and internet information indicate that the respondent has access to the internet and uses internet as the main source of information respectively.

\footnotetext{
${ }^{22} \mathrm{We}$ have also tried controlling for being active in the labor market. This variable is not significant. Results are available upon request.
} 
Table B3.

Support for European Union and Customs Union accession and work experience abroad including controls for the individual ethnic group.

\begin{tabular}{|c|c|c|c|c|c|c|}
\hline & Pro EU & Pro EU & Pro EU & Pro CU & Pro CU & Pro CU \\
\hline \multirow[t]{2}{*}{ Returnee East } & $-0.452 * *$ & $-0.453 * *$ & $-0.452 * *$ & $0.735 * * *$ & $0.735 * * *$ & $0.732 * * *$ \\
\hline & $(0.220)$ & $(0.222)$ & $(0.225)$ & $(0.173)$ & $(0.173)$ & $(0.174)$ \\
\hline \multirow[t]{2}{*}{ Returnee West } & $0.700 * *$ & $0.768 * * *$ & $0.743 * *$ & -0.196 & -0.237 & -0.211 \\
\hline & $(0.279)$ & $(0.295)$ & $(0.289)$ & $(0.283)$ & $(0.288)$ & $(0.276)$ \\
\hline \multirow[t]{2}{*}{ Higher education } & $0.424 * * *$ & $0.477 * * *$ & $0.474 * * *$ & -0.242 & $-0.283^{*}$ & $-0.266^{*}$ \\
\hline & $(0.162)$ & $(0.162)$ & $(0.159)$ & $(0.155)$ & $(0.154)$ & $(0.148)$ \\
\hline \multirow[t]{2}{*}{ Romanian language } & $1.087 * * *$ & $1.512 * * *$ & $1.683 * * *$ & $-0.999 * * *$ & $-1.340 * * *$ & $-1.448 * * *$ \\
\hline & $(0.275)$ & $(0.214)$ & $(0.251)$ & $(0.301)$ & $(0.223)$ & $(0.327)$ \\
\hline \multirow[t]{2}{*}{ Age } & $-0.105 * *$ & $-0.115^{* *}$ & $-0.120 * * *$ & 0.104 & 0.111 & 0.110 \\
\hline & $(0.046)$ & $(0.046)$ & $(0.044)$ & $(0.072)$ & $(0.072)$ & $(0.073)$ \\
\hline \multirow[t]{2}{*}{ Revenue } & 0.002 & 0.002 & -0.005 & -0.032 & -0.033 & -0.027 \\
\hline & $(0.036)$ & $(0.037)$ & $(0.037)$ & $(0.033)$ & $(0.034)$ & $(0.034)$ \\
\hline \multirow[t]{2}{*}{ Female } & -0.028 & -0.038 & -0.057 & -0.172 & -0.166 & -0.148 \\
\hline & $(0.117)$ & $(0.118)$ & $(0.118)$ & $(0.134)$ & $(0.136)$ & $(0.141)$ \\
\hline \multirow[t]{2}{*}{ rural } & -0.031 & -0.062 & -0.040 & -0.031 & -0.005 & -0.025 \\
\hline & $(0.184)$ & $(0.183)$ & $(0.182)$ & $(0.199)$ & $(0.199)$ & $(0.195)$ \\
\hline \multirow[t]{2}{*}{ Internet access } & $0.209^{*}$ & $0.213^{*}$ & $0.231 *$ & 0.054 & 0.054 & 0.035 \\
\hline & $(0.117)$ & $(0.119)$ & $(0.118)$ & $(0.169)$ & $(0.167)$ & $(0.169)$ \\
\hline \multirow[t]{2}{*}{ Internet information } & $0.525^{* *}$ & $0.449 * *$ & $0.478 * *$ & -0.234 & -0.181 & -0.220 \\
\hline & $(0.220)$ & $(0.221)$ & $(0.221)$ & $(0.213)$ & $(0.205)$ & $(0.209)$ \\
\hline \multirow[t]{2}{*}{ Moldovan or Romanian } & $0.930 * * *$ & & & $-0.819 * * *$ & & \\
\hline & $(0.180)$ & & & $(0.286)$ & & \\
\hline \multirow[t]{2}{*}{ Russian } & & $-0.776^{* * *}$ & & & $0.844 * * *$ & \\
\hline & & $(0.254)$ & & & (0.319) & \\
\hline \multirow[t]{2}{*}{ Ukrainian } & & & -0.011 & & & 0.386 \\
\hline & & & $(0.253)$ & & & $(0.302)$ \\
\hline \multirow[t]{2}{*}{ Constant } & $-1.362 * * *$ & $-0.837 * *$ & $-0.979 * * *$ & $1.658 * * *$ & $1.168 * * *$ & $1.264 * * *$ \\
\hline & $(0.327)$ & $(0.376)$ & $(0.367)$ & $(0.449)$ & $(0.327)$ & $(0.347)$ \\
\hline Chi2 & 386.68 & 331.79 & 303.69 & 144.70 & 178.44 & 153.97 \\
\hline $\mathrm{P}$ & 0.00 & 0.00 & 0.00 & 0.00 & 0.00 & 0.00 \\
\hline$N$ & 1,192 & 1,192 & 1,192 & 1,192 & 1,192 & 1,192 \\
\hline
\end{tabular}

$* p<0.1$; ** $p<0.05 ; * * * p<0.01$. Logistic regressions. Robust standard errors clustered at the district level in parentheses. Returnee East and returnee West are dummies for work experience in a former Soviet country and a Western country respectively. Pro EU and pro CU are dummies indicating that the respondent would vote in favour of accession to the European Union and Customs Union (with Russia, Belarus and Kazakhstan) respectively. Romanian language indicates that the respondent chose to conduct the interview in Romanian. Internet access and internet information indicate that the respondent has access to the internet and uses internet as the main source of information respectively. Moldovan, Romanian, Russian and Ukrainian indicate respondent's ethnic group. 
Table B4

Support for European Union and Customs Union accession and work experience abroad including controls for economic indicators at the district level.

\begin{tabular}{lcc}
\hline & Pro EU & Pro CU \\
\hline Returnee East & -0.407 & 0.711 \\
& $(0.230)^{*}$ & $(0.176)^{* * *}$ \\
Returnee West & 0.739 & -0.223 \\
& $(0.264)^{* * *}$ & $(0.309)$ \\
Returnee East and West & 0.610 & -0.446 \\
Romanian language & $(0.398)$ & $(0.365)$ \\
& 1.560 & -1.753 \\
Female & $(0.267)^{* * *}$ & $(0.304)^{* * *}$ \\
Age & -0.048 & -0.188 \\
Higher education & $(0.121)$ & $(0.141)$ \\
Revenue & -0.186 & 0.106 \\
Rural & $(0.038)^{* * *}$ & $(0.063)^{*}$ \\
Value production district & 0.564 & -0.388 \\
Wage district & $(0.140)^{* * *}$ & $(0.157)^{* *}$ \\
Production units district & 0.021 & -0.013 \\
Constant & $(0.036)$ & $(0.037)$ \\
$N$ & -0.138 & 0.034 \\
& $(0.230)$ & $(0.162)$ \\
Not $p<01 ; * 0.000$
\end{tabular}

Note: $* p<0.1 ; * * p<0.05 ; * * * p<0.01$. Logistic regressions. Robust standard errors clustered at the district level in parentheses. Value production unit district, wage district and production units districts measure the gross value added, average wage and the number of firms/production units in the district in 2012 (source: National Bureau of Statistics). Returnee East and returnee West are dummies for work experience in a former Soviet country and a Western country respectively. Pro EU and pro CU are dummies indicating that the respondent would vote in favour of accession to the European Union and Customs Union (with Russia, Belarus and Kazakhstan) respectively. Romanian language indicates that the respondent chose to conduct the interview in Romanian. 
Table B5

Support for European Union and Customs Union accession and work experience abroad including controls for ethnic composition at the district level.

\begin{tabular}{lcc}
\hline & Pro EU & Pro CU \\
\hline Returnee East & -0.397 & 0.678 \\
Returnee West & $(0.220)^{*}$ & $(0.171)^{* * *}$ \\
& 0.784 & -0.265 \\
Returnee East and West & $(0.270)^{* * *}$ & $(0.299)$ \\
& 0.629 & -0.454 \\
Romanian language & $(0.405)$ & $(0.380)$ \\
& 1.516 & -1.667 \\
Female & $(0.290)^{* * *}$ & $(0.336)^{* * *}$ \\
Age & -0.046 & -0.189 \\
& $(0.124)$ & $(0.138)$ \\
Higher education & -0.175 & 0.104 \\
Revenue & $(0.040)^{* * *}$ & $(0.064)$ \\
Rural & 0.551 & -0.389 \\
Ukrainians district $\%$ & $(0.131)^{* * *}$ & $(0.155)^{* *}$ \\
Russians district $\%$ & 0.005 & -0.015 \\
Gagauz district $\%$ & $(0.038)$ & $(0.036)$ \\
Constant & 0.004 & -0.061 \\
$N$ & $(0.224)$ & $(0.184)$ \\
\hline
\end{tabular}

Note: $* p<0.1 ; * * p<0.05 ; * * * p<0.01$. Logistic regressions. Robust standard errors clustered at the district level in parentheses. Returnee East and returnee West are dummies for work experience in a former Soviet country and a Western country respectively. Pro EU and pro CU are dummies indicating that the respondent would vote in favour of accession to the European Union and Customs Union (with Russia, Belarus and Kazakhstan) respectively. Romanian language indicates that the respondent chose to conduct the interview in Romanian. Ukrainians district\%, .Russians district \% and Gagauz district \% indicate the percentage of these ethnic groups in respondent's district (source: National Bureau of Statistics). 
Table B6

Support for European Union and Customs Union accession and work experience abroad including controls for demographic composition at the district level. ${ }^{23}$

\begin{tabular}{lcc}
\hline & Pro EU & Pro CU \\
\hline Returnee East & -0.388 & 0.678 \\
& $(0.229)^{*}$ & $(0.174)^{* * *}$ \\
Returnee West & 0.791 & -0.231 \\
& $(0.283)^{* * *}$ & $(0.290)$ \\
Returnee East and West & 0.651 & -0.457 \\
& $(0.413)$ & $(0.375)$ \\
Romanian language & 1.658 & -1.546 \\
Female & $(0.220)^{* * *}$ & $(0.318)^{* * *}$ \\
Age & -0.043 & -0.191 \\
& $(0.125)$ & $(0.142)$ \\
Higher education & -0.165 & 0.101 \\
& $(0.042)^{* * *}$ & $(0.065)$ \\
Revenue & 0.553 & -0.388 \\
Rural & $(0.131)^{* * *}$ & $(0.148)^{* * *}$ \\
Population65+ district & 0.009 & -0.016 \\
Constant & $(0.036)$ & $(0.034)$ \\
$N$ & -0.016 & -0.095 \\
& $(0.188)$ & $(0.206)$ \\
\end{tabular}

Note: $* p<0.1 ; * * p<0.05$; $* * * p<0.01$. Logistic regressions. Robust standard errors clustered at the district level in parentheses. Returnee East and returnee West are dummies for work experience in a former Soviet country and a Western country respectively. Pro EU and pro CU are dummies indicating that the respondent would vote in favour of accession to the European Union and Customs Union (with Russia, Belarus and Kazakhstan) respectively. Romanian language indicates that the respondent chose to conduct the interview in Romanian. Population65+ district indicates the percentage of population in the district older than 65 (source: National Burau of Statistics).

\footnotetext{
${ }^{23}$ The results are robust to including dummies for all age groups categories.
} 


\section{Table B7}

Support for European Union and Customs Union accession and work experience abroad including controls for geopolitical preferences at the district level

\begin{tabular}{|c|c|c|c|c|}
\hline & Pro EU & Pro CU & $\begin{array}{c}\text { Pro EU } \\
\text { (sample of non- } \\
\text { migrants) }\end{array}$ & $\begin{array}{c}\text { Pro CU } \\
\text { (sample of } \\
\text { non-migrants) }\end{array}$ \\
\hline Returnee East & $\begin{array}{l}-0.471^{* *} \\
(0.223)\end{array}$ & $\begin{array}{l}0.746 * * * \\
(0.172)\end{array}$ & & \\
\hline Returnee West & $\begin{array}{l}0.732 * * * \\
(0.270)\end{array}$ & $\begin{array}{l}-0.190 \\
(0.296)\end{array}$ & & \\
\hline Higher education & $\begin{array}{l}0.567 * * * \\
(0.153)\end{array}$ & $\begin{array}{l}-0.302 * * \\
(0.139)\end{array}$ & $\begin{array}{l}0.564 * * * \\
(0.182)\end{array}$ & $\begin{array}{l}-0.302 \\
(0.232)\end{array}$ \\
\hline Romanian language & $\begin{array}{l}1.606 * * * \\
(0.230)\end{array}$ & $\begin{array}{l}-1.493 * * * \\
(0.355)\end{array}$ & $\begin{array}{l}1.523 * * * \\
(0.244)\end{array}$ & $\begin{array}{l}-1.603 * * * \\
(0.358)\end{array}$ \\
\hline Age & $\begin{array}{l}-0.198 * * * \\
(0.040)\end{array}$ & $\begin{array}{l}0.132 * * \\
(0.062)\end{array}$ & $\begin{array}{l}-0.176 * * * \\
(0.038)\end{array}$ & $\begin{array}{l}0.138 * * \\
(0.067)\end{array}$ \\
\hline Revenue & $\begin{array}{c}0.009 \\
(0.034)\end{array}$ & $\begin{array}{l}-0.026 \\
(0.030)\end{array}$ & $\begin{array}{c}0.058 \\
(0.044)\end{array}$ & $\begin{array}{c}0.003 \\
(0.031)\end{array}$ \\
\hline Female & $\begin{array}{l}-0.070 \\
(0.124)\end{array}$ & $\begin{array}{l}-0.153 \\
(0.145)\end{array}$ & $\begin{array}{l}-0.310^{* *} \\
(0.152)\end{array}$ & $\begin{array}{l}-0.265 \\
(0.207)\end{array}$ \\
\hline Rural & $\begin{array}{l}-0.116 \\
(0.168)\end{array}$ & $\begin{array}{c}0.009 \\
(0.188)\end{array}$ & $\begin{array}{c}0.055 \\
(0.204)\end{array}$ & $\begin{array}{c}0.028 \\
(0.196)\end{array}$ \\
\hline $\begin{array}{l}\text { EU versus CU district } \\
\text { (excluding own) }\end{array}$ & $0.386^{*}$ & -0.268 & 0.348 & -0.186 \\
\hline & $(0.227)$ & $(0.332)$ & $(0.224)$ & $(0.331)$ \\
\hline Constant & $\begin{array}{l}-1.312 * * * \\
(0.500)\end{array}$ & $\begin{array}{l}1.743 * * \\
(0.746)\end{array}$ & $\begin{array}{l}-1.424 * * * \\
(0.521)\end{array}$ & $\begin{array}{l}1.604 * * \\
(0.703)\end{array}$ \\
\hline Chi2 & 300.51 & 152.32 & 173.32 & 90.39 \\
\hline $\mathrm{P}$ & 0.00 & 0.00 & 0.00 & 0.00 \\
\hline$N$ & 1,186 & 1,186 & 873 & 873 \\
\hline
\end{tabular}

Logistic regressions. Robust standard errors clustered at the district level in parentheses. EU versus CU is a five point measure indicating respondents' position on the pro CU-pro EU preference spectrum. EU versus CU district (excluding own) is the district average of the variable EU versus CU, excluding the respondent's own observation to avoid endogeneity. Returnee East and returnee West are dummies for work experience in a former Soviet country and a Western country respectively. Pro EU and pro CU are dummies indicating that the respondent would vote in favour of accession to the European Union and Customs Union (with Russia, Belarus and Kazakhstan) respectively. Romanian language indicates that the respondent chose to conduct the interview in Romanian. 


\section{Table B8.}

Support for European Union and Customs Union accession and work experience abroad including controls for geopolitical preferences at the district level (second stage IV)

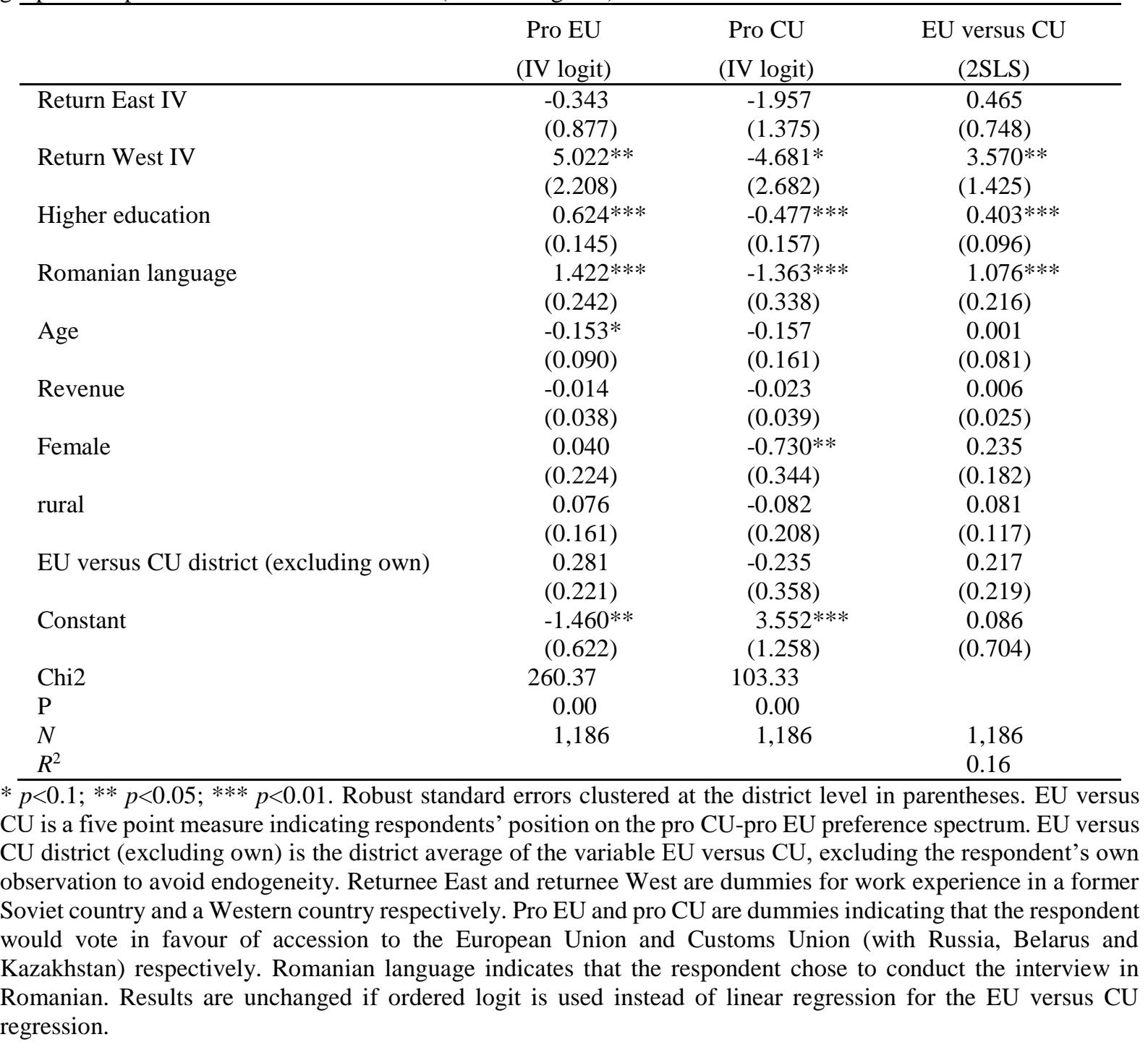


Table B9

Support for European Union and Customs Union accession and work experience abroad, alternative estimation method.

\begin{tabular}{|c|c|c|c|c|}
\hline & $\begin{array}{c}\text { EU_versus_CU } \\
(\mathrm{OLS})\end{array}$ & $\begin{array}{c}\text { EU_versus_CU } \\
\text { (IV) }\end{array}$ & $\begin{array}{l}\text { Returnee West } \\
\text { (first stage) }\end{array}$ & $\begin{array}{c}\text { Returnee East } \\
\text { (first stage) }\end{array}$ \\
\hline Higher education & $\begin{array}{l}0.318^{* * * *} \\
(0.109)\end{array}$ & $\begin{array}{l}0.343^{* *} \\
(0.135)\end{array}$ & $\begin{array}{l}-0.017 \\
(0.021)\end{array}$ & $\begin{array}{l}-0.033 \\
(0.03)\end{array}$ \\
\hline Romanian language & $\begin{array}{l}1.250 * * * \\
(0.093)\end{array}$ & $\begin{array}{l}1.113^{* * *} \\
(0.119)\end{array}$ & $\begin{array}{l}0.034 * * \\
(0.015)\end{array}$ & $\begin{array}{l}-0.02 \\
(0.03)\end{array}$ \\
\hline Age & $\begin{array}{l}-0.109^{* * * *} \\
(0.041)\end{array}$ & $\begin{array}{l}-0.138 \\
(0.105)\end{array}$ & $\begin{array}{l}-0.006 \\
(0.006)\end{array}$ & $\begin{array}{c}-0.098 * * * \\
(0.009)\end{array}$ \\
\hline Revenue & $\begin{array}{c}0.021 \\
(0.020)\end{array}$ & $\begin{array}{l}-0.002 \\
(0.025)\end{array}$ & $\begin{array}{l}0.007^{* * *} \\
(0.004)\end{array}$ & $\begin{array}{l}-0.06 \\
(0.06)\end{array}$ \\
\hline Female & $\begin{array}{l}-0.006 \\
(0.084)\end{array}$ & $\begin{array}{l}-0.032 \\
(0.209)\end{array}$ & $\begin{array}{l}-0.002 \\
(0.015)\end{array}$ & $\begin{array}{l}-0.18 * * * \\
(0.02)\end{array}$ \\
\hline Rural & $\begin{array}{c}0.006 \\
(0.089)\end{array}$ & $\begin{array}{c}0.138 \\
(0.119)\end{array}$ & $\begin{array}{l}-0.050^{* *} \\
(0.02)\end{array}$ & $\begin{array}{l}-0.002 \\
(0.03)\end{array}$ \\
\hline Returnee West & $\begin{array}{l}0.340 * * \\
(0.159)\end{array}$ & $\begin{array}{l}3.084 * \\
(1.599)\end{array}$ & & \\
\hline Returnee East & $\begin{array}{l}-0.487 * * * \\
(0.111)\end{array}$ & $\begin{array}{l}-0.975 \\
(0.930)\end{array}$ & & \\
\hline $\begin{array}{l}\text { District diaspora West } \\
\text { (2004) }\end{array}$ & & & $67.767 * * *$ & 15.45 \\
\hline $\begin{array}{l}\text { District diaspora East } \\
\text { (2004) }\end{array}$ & & & $\begin{array}{l}(21.33) \\
-1.497 * * *\end{array}$ & $\begin{array}{l}(27.75) \\
2.02 * * *\end{array}$ \\
\hline & & & $(0.371)$ & $(0.56)$ \\
\hline _cons & $\begin{array}{l}1.168 * * * \\
(0.218)\end{array}$ & $\begin{array}{l}1.318^{* *} \\
(0.656)\end{array}$ & $\begin{array}{c}0.066^{*} \\
(0.038)\end{array}$ & $\begin{array}{l}0.50^{* * *} \\
(0.06)\end{array}$ \\
\hline $\mathrm{R} 2$ & 0.17 & & 0.03 & 0.14 \\
\hline $\begin{array}{l}\text { Wald Chi2 } \\
\text { Prob }>\text { Chi2 }\end{array}$ & & $\begin{array}{l}192.28 \\
(0.000)\end{array}$ & & \\
\hline $\begin{array}{l}\text { Robust F }(2,1177)- \\
\text { (first stage) } \\
\text { Prob }>F\end{array}$ & & & $\begin{array}{c}8.492 \\
(0.000)\end{array}$ & $\begin{array}{l}11.81 \\
(0.000)\end{array}$ \\
\hline$N$ & 1,186 & 1,186 & 1186 & 1186 \\
\hline
\end{tabular}

Note: $* p<0.1 ; * * p<0.05 ; * * * p<0.01$. Robust standard errors in parentheses. Coefficients estimated with ordinary least squares in column 1 and two stage least squares (STATA's ivregress command) in column 2. EU versus CU is a five point measure indicating respondents' position on the pro $\mathrm{CU}$-pro EU preference spectrum. District diaspora West (2004) indicates the percentage of the district population living in the West in 2004. District diaspora East (2004) indicates the percentage of the district population living in the a former Soviet country in 2004 Returnee East and returnee West are dummies for work experience in a former Soviet country and a Western country respectively. Romanian language indicates that the respondent chose to conduct the interview in Romanian. 


\section{Table B10}

Support for European accession, controlling for districts bordering Romania

\begin{tabular}{|c|c|c|}
\hline & Pro EU & $\begin{array}{c}\text { Pro EU } \\
\text { (sample of non } \\
\text { migrants only) }\end{array}$ \\
\hline Returnee East & $\begin{array}{l}-0.409 * \\
(0.237)\end{array}$ & \\
\hline Returnee West & $\begin{array}{l}0.822 * * * \\
(0.290)\end{array}$ & \\
\hline Returnee East and West & $\begin{array}{c}0.539 \\
(0.429)\end{array}$ & \\
\hline Higher education & $\begin{array}{l}0.570 * * * \\
(0.152)\end{array}$ & $\begin{array}{l}0.576 \text { *** } \\
(0.182)\end{array}$ \\
\hline Romanian language & $\begin{array}{l}1.667 * * * \\
(0.220)\end{array}$ & $\begin{array}{l}1.610 \text { *** } \\
(0.212)\end{array}$ \\
\hline Age & $\begin{array}{l}-0.188^{* * * *} \\
(0.040)\end{array}$ & $\begin{array}{l}-0.180 * * * \\
(0.040)\end{array}$ \\
\hline Revenue & $\begin{array}{c}0.009 \\
(0.032)\end{array}$ & $\begin{array}{c}0.056 \\
(0.042)\end{array}$ \\
\hline Female & $\begin{array}{l}-0.045 \\
(0.127)\end{array}$ & $\begin{array}{l}-0.307 * * \\
(0.154)\end{array}$ \\
\hline Rural & $\begin{array}{l}-0.080 \\
(0.191)\end{array}$ & $\begin{array}{c}0.097 \\
(0.225)\end{array}$ \\
\hline District border Romania & $\begin{array}{l}-0.116 \\
(0.299)\end{array}$ & $\begin{array}{l}-0.129 \\
(0.338)\end{array}$ \\
\hline _cons & $\begin{array}{l}-0.706 * * \\
(0.319)\end{array}$ & $\begin{array}{l}-0.825^{* *} \\
(0.343)\end{array}$ \\
\hline Chi2 & 250.97 & 154.50 \\
\hline $\mathrm{P}$ & 0.00 & 0.00 \\
\hline $\mathrm{N}$ & 1,192 & 876 \\
\hline
\end{tabular}

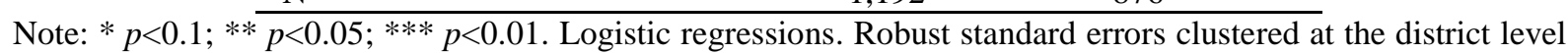
in parentheses. Returnee East and returnee West are dummies for work experience in a former Soviet country and a Western country respectively. Romanian language indicates that the respondent chose to conduct the interview in Romanian.

\section{Table B11}

Multicollinearity diagnostics

\begin{tabular}{lc}
\hline Variable & VIF \\
\hline & \\
Rural & 1.29 \\
Revenue & 1.28 \\
Age & 1.17 \\
Returnee East & 1.17 \\
Higher Education & 1.15 \\
Romanian Language & 1.15 \\
Female & 1.08 \\
Returnee West & 1.04 \\
& \\
Mean VIF & 1.17 \\
\hline
\end{tabular}




\section{Appendix C. First stage regressions.}

Table C1

Probability to have worked in the East and West as a function of district diaspora to East and West in 2004

\begin{tabular}{|c|c|c|}
\hline & Returnee East & Returnee West \\
\hline District diaspora West (2004) & $\begin{array}{c}229.087 \\
(236.098)\end{array}$ & $\begin{array}{l}1,143.828 * * * \\
(327.294)\end{array}$ \\
\hline District diaspora East (2004) & $\begin{array}{c}15.275 * * * \\
(3.997)\end{array}$ & $\begin{array}{c}-29.592 * * * \\
(8.540)\end{array}$ \\
\hline Higher education & $\begin{array}{l}-0.315 \\
(0.244)\end{array}$ & $\begin{array}{l}-0.229 \\
(0.303)\end{array}$ \\
\hline Romanian language & $\begin{array}{l}-0.106 \\
(0.194)\end{array}$ & $\begin{array}{l}0.627 * * \\
(0.285)\end{array}$ \\
\hline Age & $\begin{array}{c}-0.779 * * * \\
(0.090)\end{array}$ & $\begin{array}{l}-0.097 \\
(0.100)\end{array}$ \\
\hline Revenue & $\begin{array}{l}-0.014 \\
(0.060)\end{array}$ & $\begin{array}{l}0.116 * * \\
(0.058)\end{array}$ \\
\hline Female & $\begin{array}{c}-1.417 * * * \\
(0.204)\end{array}$ & $\begin{array}{l}-0.371 \\
(0.274)\end{array}$ \\
\hline rural & $\begin{array}{l}-0.030 \\
(0.221)\end{array}$ & $\begin{array}{c}-0.812 * * * \\
(0.302)\end{array}$ \\
\hline Constant & $\begin{array}{r}0.419 \\
(0.570)\end{array}$ & $\begin{array}{c}-2.743 * * * \\
(0.679)\end{array}$ \\
\hline Wald chi2(8) & 302.66 & 47.79 \\
\hline Prob> chi2 & 0.000 & 0.000 \\
\hline Pseudo R2 & 0.16 & 0.07 \\
\hline$N$ & 1,192 & 1,192 \\
\hline
\end{tabular}

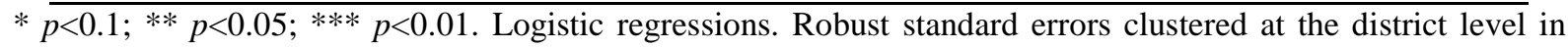
parentheses. District diaspora West (2004) indicates the percentage of the district population living in the West in 2004. District diaspora East (2004) indicates the percentage of the district population living in the East in 2004. Returnee East and returnee West are dummies for work experience in a former Soviet country and a Western country respectively. Romanian language indicates that the respondent chose to conduct the interview in Romanian. 


\section{Appendix D: Perceived benefits of joining the European Union and the Customs Union}

Table D1

Biggest advantage of joining the European Union and work experience abroad.

\begin{tabular}{|c|c|c|c|c|}
\hline & Non migrants & Returnees East & Returnees West & Returnees East and West \\
\hline Visa liberalisation & 155 & 28 & 22 & 5 \\
\hline column $\%$ & 17,15 & 12,73 & 26,51 & 16,67 \\
\hline Jobs & 64 & 36 & 7 & 3 \\
\hline column $\%$ & 7,08 & 16,36 & 8,43 & 10 \\
\hline Higher living standards & 87 & 18 & 8 & 9 \\
\hline column $\%$ & 9,62 & 8,18 & 9,64 & 30 \\
\hline Economic development & 41 & 10 & 9 & 2 \\
\hline column $\%$ & 4,54 & 4,55 & 10,84 & 6,67 \\
\hline Higher wages and pensions & 28 & 11 & 5 & 1 \\
\hline column $\%$ & 3,1 & 5 & 6,02 & 3,33 \\
\hline There are no benefits & 209 & 66 & 12 & 2 \\
\hline column \% & 23,12 & 30 & 14,46 & 6,67 \\
\hline I do not know & 224 & 42 & 8 & 6 \\
\hline column $\%$ & 24,78 & 19,09 & 9,64 & 20 \\
\hline Other & 79 & 8 & 10 & 2 \\
\hline column \% & 8,73 & 3,63 & 12,01 & 6,66 \\
\hline Total & 904 & 220 & 83 & 30 \\
\hline column \% & 100 & 100 & 100 & 100 \\
\hline
\end{tabular}

Note: Distribution of answers to the question: "What is the biggest advantage of joining the European Union?". Response categories with fewer than $5 \%$ of responses for at least one column were grouped together in the category other. They include: cheaper energy, lower prices, better collaboration, financial help, respect for the retired, less corruption, more exports, more investments, development of education and culture, improvement of the judicial system, respect of rights, communication language, infrastructure development, bigger market, tourism development, change in people's way of thinking and acting, return of migrants, solution for the political crisis, better local infrastructure, I have relatives in the EU, Romanian language will keep its status and security maintenance. 
Table D2

Biggest advantage of joining the Customs Union and work experience abroad.

\begin{tabular}{|c|c|c|c|c|}
\hline & Non migrants & Returnees East & Returnees West & Returnees East and West \\
\hline Visa liberalisation & 38 & 13 & 1 & 0 \\
\hline Column \% & 4,2 & 5,91 & 1,2 & 0 \\
\hline Jobs & 53 & 28 & 4 & 2 \\
\hline Column \% & 5,86 & 12,73 & 4,82 & 6,67 \\
\hline Cheaper energy & 145 & 40 & 12 & 5 \\
\hline Column \% & 16,04 & 18,18 & 14,46 & 16,67 \\
\hline Financial aid & 47 & 12 & 2 & 1 \\
\hline Column \% & 5,2 & 5,45 & 2,41 & 3,33 \\
\hline Product exports & 32 & 12 & 8 & 2 \\
\hline Column \% & 3,54 & 5,45 & 9,64 & 6,67 \\
\hline Higher living standards & 48 & 10 & 1 & 1 \\
\hline Column \% & 5,31 & 4,55 & 1,2 & 3,33 \\
\hline Economic development & 39 & 5 & 6 & 4 \\
\hline Column \% & 4,31 & 2,27 & 7,23 & 13,33 \\
\hline Access to markets & 42 & 12 & 2 & 1 \\
\hline Column \% & 4,65 & 5,45 & 2,41 & 3,33 \\
\hline No benefits & 138 & 22 & 28 & 8 \\
\hline Column \% & 15,27 & 10 & 33,73 & 26,67 \\
\hline I do not know & 244 & 36 & 15 & 6 \\
\hline Column \% & 26,99 & 16,36 & 18,07 & 20 \\
\hline Other & 78 & 30 & 4 & 0 \\
\hline Column \% & 8,62 & 13,61 & 4,8 & 0 \\
\hline Total & 904 & 220 & 83 & 30 \\
\hline Column \% & 100.00 & 100.00 & 100.00 & 100.00 \\
\hline
\end{tabular}

Note: Distribution of answers to the question: "What is the biggest advantage of joining the Customs Union?". Response categories with fewer than $5 \%$ of responses for at least one column were grouped together in the category other. They include: they have everything, lower prices, better collaboration, higher wages and pensions, respect for the retired, reduction of corruption, it is closer, higher investments, resolution of the Transnistrian conflict, improvement of education and culture, improvement of the judicial system, easy language of communication, common past, Moldova would get rid of debts, tourism development, lower customs duties, return of Migrants, many Moldovans have Russian citizenship, introduction of quality standards, better governance, closed borders, I have family there. 


\section{References.}

Alesina, A. And N. Fuchs-Schundeln (2007). Goodbye Lenin (or Not?): The Effect of Communism on People's Preferences. Americal Economic Review 97(4): 1507-1528.

Barsbai, T., H. Rapoport, A. Steinmayr and C. Trebesch (2017). The Effect of Labor Migration on the Diffusion of Democracy: Evidence from a Former Soviet Republic. American Economic Journal: Applied Economics.

Batista, A. and P. Vicente (2011). Do migrants improve governance at home? Evidence from a voting experiment. World Bank Economic Review 25(1): 77-104.

Beine, M., F. Docquier and M. Schiff. International Migration, transfer of norms and home country fertility. Canadian Journal of Economics 46(4): 1406-1430.

Beine, M., Sekkat, K., 2013. Skilled migration and the transfer of institutional norms. IZA Journal of Migration 2 (1), 9.

Chauvet, L. and M. Mercier (2014). Do return migrants transfer political norms to their origin countries? Evidence from Mali. Journal of Comparative Economics 42 (3): 630-651.

Docquier, F., E. Lodigiani, H. Rapoport and M. Schiff (2016). Emigration and Democracy. Journal of Development Economics 120: 209-223.

European Commission (2005). EU-Moldova Action Plan. Retrieved from http://www.enpiinfo.eu/library/content/eu-moldova-action-plan.

Fidrmuc, J., and O. Doyle., (2005). Does Where You Live Affect How You Vote? An Analysis of Migrant Voting Behavior. Paper presented at the Second IZA Workshop: EU Enlargement and the Labor Markets, September 2007, IZA, Bonn. 
Gorlich, D. and C. Trebesch (2008). Seasonal Migration and Networks-Evidence on Moldova's Labour Exodus. Review of World Economics 144 (1): 107-133.

IOM (2012). Extended Migration Profile of the Republic of Moldova. International Organization for Migration (IOM) Mission to Moldova.

Institute for Public Policy (2015). Barometer of Public Opinion-November 2015 final report. Retrieved from http://www.ipp.md/libview.php?l=en\&idc=156\&id=760.

Korosteleva, E. (2010) Moldova's European Choice: 'Between Two Stools'? Europe-Asia Studies, 62 (8): 1267-1289.

Levitt, P. (1998). Migration driven local level forms of cultural diffusion. The International Migration Review 32 (4): 926-948.

Luecke, M., T. Omar Mahmoud, and P. Pinger (2007). Patterns and Trends of Migration and Remittances in Moldova - The CBSAXA Survey 2006, International Organization for Migration (IOM), Chisinau.

Li, X., McHale, J., 2006. Does brain drain lead to institutional gain? A cross country empirical investigation. Manuscript, Queen’s University

Mercier, M., 2016. The Return of the Prodigy Son: Do Return Migrants make Better Leaders? Journal of Development Economics 122: 76-91.

Nikolova, M., M. Roman, K.F. Zimmermann (2017). Left behind but doing good? Civic engagement in two post-socialist countries. Journal of Comparative Economics 45; 658-684. 
Perez-Armendariz, C. and Crow, D. (2010). Do migrants remit democracy? International migration, Political Beliefs and Behavior in Mexico. Comparative Political Studies 43 (1):119148.

Pinger, P. (2007). Come back or stay? - Spend here or there?: Temporary versus permanent migration and remittance patterns in the Republic of Moldova. Kiel advanced studies working papers 438 .

Pfutze, T., 2012. Does migration promote democratization? Evidence from the Mexican transition. Journal of Comparative Economics 40 (2), 159-175.

Spilimbergo, A. (2009). Democracy and Foreign Education. American Economic Review, 99(1): 528-543.

Stark, O., M. Micevska and J. Mycielski (2009).Relative Poverty as a determinant of migration: Evidence from Poland. Economics Letters 103(3): 119-122. 